NBER WORKING PAPER SERIES

\title{
UNPACKING A MULTI-FACETED PROGRAM TO BUILD SUSTAINABLE INCOME FOR THE VERY POOR
}

\author{
Abhijit Banerjee \\ Dean Karlan \\ Robert Darko Osei \\ Hannah Trachtman \\ Christopher Udry \\ Working Paper 24271 \\ http://www.nber.org/papers/w24271 \\ NATIONAL BUREAU OF ECONOMIC RESEARCH \\ 1050 Massachusetts Avenue \\ Cambridge, MA 02138 \\ February 2018, Revised April 2020
}

Approval from the Yale University Human Subjects Committee, IRB \#0705002656, 1002006308, 1006007026, and 1011007628; and from the Innovations for Poverty Action Human Subjects Committee, IRB Protocol \#19.08January-002, 09December-003, 59.10June-002, and 10November-003.494. Thanks to the Ford Foundation, and 3ie for funding. Thanks to Nathan Barker, Caton Brewster, Abubakari Bukari, David Bullon Patton, Sébastien Fontenay, Angela Garcia, Yann Guy, Samantha Horn, Sana Khan, Hideto Koizumi, Matthew Lowes, Elizabeth Naah, Michael Polansky, Elana Safran, Sneha Stephen, Rachel Strohm, and Stefan Vedder for outstanding research assistance and project management, and in particular Bram Thuysbaert for collaboration. The authors would like to thank the leadership and staff at Presbyterian Agricultural Services (PAS) for their partnership. Thanks to Frank DeGiovanni of the Ford Foundation, Syed Hashemi of BRAC University, and Aude de Montesquiou and Alexia Latortue of CGAP for their support and encouragement of the research. No authors have any real or apparent conflicts of interest, except Karlan is on the Board of Directors of Innovations for Poverty Action, which participated in oversight of the implementation. All data and code are available at the IPA Dataverse (doi pending). The views expressed herein are those of the authors and do not necessarily reflect the views of the National Bureau of Economic Research.

NBER working papers are circulated for discussion and comment purposes. They have not been peer-reviewed or been subject to the review by the NBER Board of Directors that accompanies official NBER publications.

(C) 2018 by Abhijit Banerjee, Dean Karlan, Robert Darko Osei, Hannah Trachtman, and Christopher Udry. All rights reserved. Short sections of text, not to exceed two paragraphs, may be quoted without explicit permission provided that full credit, including () notice, is given to the source. 
Unpacking a Multi-Faceted Program to Build Sustainable Income for the Very Poor Abhijit Banerjee, Dean Karlan, Robert Darko Osei, Hannah Trachtman, and Christopher Udry NBER Working Paper No. 24271

February 2018, Revised April 2020

JEL No. D12,O12,O17

\section{ABSTRACT}

A multi-faceted program comprising a grant of productive assets, training, coaching, and savings has been found to build sustainable income for those in extreme poverty. We focus on two important questions: whether a mere grant of productive assets would generate similar impacts (it does not), and whether access to a savings account and a deposit collection service would generate similar impacts (it does not).

$\begin{array}{ll}\text { Abhijit Banerjee } & \text { Hannah Trachtman } \\ \text { Department of Economics, E52-540 } & \begin{array}{l}\text { Department of Economics } \\ \text { Yale University }\end{array} \\ \text { MIT } & \text { PO Box 208268 } \\ \text { 50 Memorial Drive } & \text { New Haven, CT 06511 } \\ \text { Cambridge, MA 02142 } & \text { htrachtm@ gmail.com } \\ \text { and NBER } & \\ \text { banerjee@mit.edu } & \text { Christopher Udry } \\ \text { Dean Karlan } & \text { Northwestern University } \\ \text { Kellogg Global Hub } & \text { Department of Economics } \\ \text { Northwestern University } & \text { Weinberg College of Arts and Sciences } \\ \text { 2211 Campus Drive } & \text { 2211 Campus Drive \#3247 } \\ \text { Evanston, IL 60208 } & \text { Evanston, IL 60208 } \\ \text { and CEPR } & \text { and NBER } \\ \text { and also NBER } & \text { christopher.udry @ northwestern.edu } \\ \text { dean.karlan@gmail.com } & \\ \text { Robert Darko Osei } & \\ \text { ISSER } \\ \text { rdosei@isser.edu.gh }\end{array}$

A randomized controlled trials registry entry is available at https://www.socialscienceregistry.org/trials/2689 


\section{Introduction}

One of the most exciting ideas in the fight against extreme poverty is the discovery that a focused multifaceted intervention can durably unleash the productive potential of a group of desperately poor people. Banerjee et al. (2015) and Bandiera et al. (2017) present impact results from seven countries for a multifaceted "graduation" program that includes at its core a transfer of productive assets, two years of training and coaching, and access to a saving account. This program successfully increased net worth, income and consumption three years after the productive assets were transferred, and in the two sites where longterm analysis is complete, impacts persisted (and indeed grew) after seven years (Banerjee et al. 2016; Bandiera et al. 2017; Balboni et al. 2020). Based on this evidence, many governments are implementing this program, often alongside further research to learn what model works best given their context and implementation capabilities. ${ }^{7}$

A better understanding of the underlying mechanisms through which the program works is critical, both for answering key theoretical questions about poverty traps and also for determining the ideal design for social protection programs. Here we explore further results from the Ghana site of Banerjee et al. (2015): we test whether two of the components, the transfer of a productive asset and the access to savings, are on their own sufficient to generate comparable impacts as the full package. The first test (the asset transfer) examines whether the only constraint on the poor is their lack of wealth, which would of course vastly simplify anti-poverty policy. The second test (the improved access to savings) examines whether the expensive wealth transfers are necessary-i.e. whether a good savings technology could suffice to help households accumulate their own wealth (albeit at a slower pace). Together, these two tests provide obvious benchmarks against which the graduation program ought to be compared.

\subsection{Background}

The interest in multi-faceted approaches comes from the rather weak evidence of long-term impact on earnings from a number of well-thought of interventions. For example, microcredit was thought, for a while, to be an intervention that has a transformative impact on the lives of the poor, but the recent evidence has not been that simple. Results on average from randomized controlled trials of expansions of microcredit tend to find no average impact on income (Banerjee, Karlan, and Zinman 2015; Meager 2019), although there are potentially promising impacts on sub-groups (Meager 2018; Banerjee et al. 2019) as well as potential long-run effects on average to communities from shocks that shutdown the entire existing microcredit market (Breza and Kinnan 2018). Similarly, basic savings accounts have not produced large impacts on income or consumption levels (Dupas et al. 2017), nor have informal savings groups (Karlan et al. 2017). For some people education or skilling is clearly that intervention, but the average returns to primary education are modest-Duflo (2001) reports a year of education increasing earnings by $7 \%$. There are relatively few credible estimates of the return to secondary schooling but a recent study by Duflo et al. (2017) reports that spending three years in the vocational track of secondary schools in Ghana increases earnings by $19 \%$, which is comparable to the returns on primary schooling. However, the returns on the academic track of the secondary schools, in the same study, were indistinguishable from zero. Business training is another related idea that has received a lot of attention in recent years. However, a review of business training interventions by McKenzie and Woodruff (2014) finds little evidence typically

\footnotetext{
7 This list includes Afghanistan, Brazil, Burkina Faso, Chad, Colombia, India, Indonesia, Kenya, Lebanon, Mali, Mauritania, Mozambique, Niger, Pakistan, Paraguay, Philippines, and Senegal.
} 
of an impact on earnings for micro-entrepreneurs (which overlaps heavily with those in extreme poverty). ${ }^{8}$ The same goes for the related class of interventions which are sometimes described as hand-holding, where the trainee gets one-on-one follow up help on their business projects (Giné and Mansuri 2011).

Capital grants have a similarly mixed record. The initial work, by De Mel, McKenzie and Woodruff (2008) finds that capital grants to small business owners in Sri Lanka generate high returns (5-7\% per month). Fafchamps et al. (2014) finds even higher returns in Ghana, and Fiala et al. (2014) finds important long term impacts in Uganda. On the other hand, Berge, Bjorvatn and Tungodden (2014) in Tanzania and Karlan, Knight and Udry (2015) in Ghana finds no effect of a grants intervention with small business owners. Karlan et al. (2014) also finds no effect of cash grants on the earnings of farmers. Moreover even those studies that find positive effects of the grant on average, like De Mel, McKenzie and Woodruff (2008) and Fafchamps et al. (2014) often fail to find a positive effect on women owned businesses (on the other hand, Fiala et al. (2014) finds positive impacts on both males and females).

There is also some evidence of positive impacts on investment from transfers that are not specifically targeted to business owners. For instance, the Mexican conditional cash transfer program Progresa generated some increase in investment (estimated as $26 \%$ of the transferred amount), leading to a longer term impact on consumption (Gertler, Martinez, and Rubio-Codina 2012). Similarly, an evaluation of GiveDirectly, which gifts large amounts of cash (between 400 dollars and 1600, or 868 and 3474 in PPP terms) to low income families in Kenya (not conditional on being business owners) finds significant consumption effects that last beyond the actual period of the payments, but fade out relatively quickly (Haushofer and Shapiro 2016).

Finally, two cash grant studies in Uganda (Blattman, Fiala, and Martinez 2014; Blattman et al. 2016) find a strong and durable positive effect, stronger than most of the above cited studies, but they combine the transfer with some handholding and nudges. One of these (Blattman et al. 2016) separately tests the importance of the ongoing handholding component of the program and finds mixed evidence.

The multi-faceted "graduation" program, is effectively an amalgam of many of the previously mentioned interventions. Interestingly, given the somewhat discouraging track record of the individual interventions, the program combining them does yield consistent and positive long-term results. In six out of seven evaluated sites, despite the fact that entirely different organizations implemented in each of the six locations, the program generated economically meaningful, cost effective, and sustained positive average impacts on earnings, consumption and other welfare measures over at least three years. Moreover, the trajectories of the beneficiaries continue to diverge from that of the control group in the two places, Bangladesh and India, where there are data from a seven-year and a ten-year follow up. The program combines a capital grant in the form of a business asset (typically livestock), some business training/hand-

\footnotetext{
${ }^{8}$ It is possible that there are higher returns to certain more specialized skilling interventions. For example, Attanasio, Kugler, and Meghir (2011) reports high returns to a specific vocational education intervention in Colombia. However, Kugler, Saavedra, and Prada (2015) reports more modest returns, also in Colombia, and Bausch et al. (2016) finds no changes in employment outcomes in Morocco. Furthermore, business training taught with simple rules-of-thumb has been found to be more effective than a more traditional curriculum (Drexler, Fischer, and Schoar 2014). Larger impacts have been found from consulting to small and medium enterprises (Bloom et al. 2012; Bruhn, Karlan, and Schoar 2018).
} 
holding, some short-term consumption support, and help with saving through savings collection services. While there was no explicit rule that required the beneficiary be a woman, in a number of countries (Bangladesh, Ghana, India, Pakistan) there was some focus on women through eligibility requirements and at least in Ghana, India, and Bangladesh, most of the direct beneficiaries were women.

BRAC, the organization that was instrumental in developing this program, has always argued that there are complementarities between the program's pieces. The consumption support is argued to help the families get through the initial setup phase for their business without feeling the pressure to sell or consume the asset, while the training and the hand-holding is argued to help them not make elementary mistakes and stay motivated during the same period. The savings accounts then help households save their earnings, and convert savings into future lump investments for the household or business.

However, while the complementarity argument is plausible based on the above evidence, it could also be that the locations where these capital grants and business training have been tested were less conducive than the locations for the graduation program in terms of getting households to make long-term investments. Or it could be that the population of the extreme poor targeted by the graduation program is different from the populations targeted by those other interventions. The graduation programs deliberately target the poorest of the poor, whereas the other programs are often more inclusive of a wider set of poor households. It therefore remains logically possible that the individual components would work if they were similarly targeted.

\subsection{What we do here}

We examine whether, for the population targeted by the graduation program, it is possible to get similar results with just one of the main components of the program. We use two additional experimental arms from the Ghana site of Banerjee et al. (2015) to examine whether the savings component alone or the grant of goats alone (the most common asset transferred in the graduation program) generate long-term improvements in income and consumption comparable to the graduation program in the same population.

The savings-only program has statistically significant positive effects on financial inclusion and consumption at two years, but both effects are much weaker by the three-year mark. The asset-only treatment has no evidence of any positive welfare effects after either two years or three years. These are important when contrasted with the full graduation program, which at the three-year mark yielded statistically significant positive effects on all five of our indicators.

We then work to unpack these differences. We start by first examining some of the mechanisms associated with changes in the full graduation treatment. We find that the graduation program's strong positive effect on income is driven by increased business income, crop income, and animal revenue, and the positive effect on assets is driven almost entirely by livestock. Furthermore, importantly (and using an additional experimental variation of the full graduation program with and without the savings component), we find that even graduation households without the savings component are saving significantly more than control households.

Next we turn to our detailed savings data in order to understand why participants in the savings-only intervention were not able to save to accumulate assets or start similarly profitable businesses. We show that the graduation program with the savings component is much more successful than the savings-only program in generating savings, even when the savings-only program had a $50 \%$ match rate (an additional 
experimental treatment arm). Perhaps this is saying that people need earnings in order to save, or that the coaching and handholding was critical for nudging the savings to be spent on investments. In sum, the savings-only component did not appear to generate savings that enabled households to start profitable businesses, or to generate persistent effects on a financial inclusion index.

We then ask why the households who only received assets were similarly unable to accumulate assets or start profitable businesses. We find that although asset-only households do own more goats than control households after both two and three years, they own fewer goats than graduation households, suggesting that they were unable to hold onto or breed their goats the way households in the graduation program did. Moreover, they own less total livestock than graduation households, implying that they were more likely to get rid of other livestock. The evidence suggests that the additional training and consumption support enabled graduation households (perhaps through a capabilities effect) to accumulate more goats while keeping other livestock as well, ultimately making them more successful in building businesses that persistently generate income. Using consumption as the final, primary outcome measure for which to calculate benefits, the full program yields a $1.2 x$ benefit-cost ratio, whereas we cannot reject the null hypotheses that benefit-cost ratio for the asset-only and the savings-only treatment arms is zero.

\section{Graduation Program Details}

For the multi-faceted program in Ghana, Graduating from Ultra Poverty ("GUP"), implementers first identified poor communities in poor regions of the country. In each identified community, staff members then facilitated a Participatory Wealth Ranking (PWR), in which members of the community worked together to rank households by economic status. Finally, staff members returned for a verification of the households judged to be the poorest. The program was implemented by Presbyterian Agricultural Services, a local nongovernmental organization, in coordination with Innovations for Poverty Action, a non-profit research organization.

The basic GUP program involved the transfer of a productive asset; skills training for the management of the asset as well as life skills training; a weekly cash stipend for consumption support, worth between $\$ 6$ and \$9 PPP depending on family size, lasting for 3-10 months; access to a savings account at a local bank (details below in the experimental design section, as this is one of the components unpacked); and some basic health services and health education. The productive asset was provided the beginning of the program, and households were permitted to choose a package of assets from a set list. The rest of these services were delivered over two years via regular visits (typically weekly) by a field officer from the implementing organization. See Appendix Table 1 for a description of each program component, and see Banerjee et al. (2015) for more details.

\section{Experimental Methods}

\subsection{Unpacking Mechanisms Design}

Beyond the full graduation program, the experiment included four additional experimental arms designed to unpack whether specific components were sufficient on their own, and included randomization at both the village and household level.

First, we introduced a slightly reduced version of the full graduation program, a "GUP without savings" treatment arm: $50 \%$ of sample households within GUP villages were randomly assigned to the graduation 
program without savings ("GUP without savings"), and 50\% received the full graduation program (i.e., including collection of savings for deposit into a local bank by the field agent, "GUP with savings").

The second ("Asset-Only") and third (Saving Out of Ultra Poverty ("SOUP")) treatment arms are at the village-level. For each, a two-level design was maintained, thus creating treatment households in treatment villages, control households in treatment villages, and control households in control villages.

In Asset-Only villages, $50 \%$ of sample households were assigned to treatment, and received only a productive asset, without skills training on how to use it, or any of the other GUP components. These households were simply given four goats, since this was the most popular asset in GUP (71\% of households chose a package of assets that included four goats). Goats were chosen because most households chose goats in the full program, and because most households either have had or currently have goats. We wanted an asset that likely required less or no technical training in order for households to have potential to succeed with it, and that would be unlikely to be turned down by households due to lack of familiarity or experience.

In SOUP villages, 59\% of sample households were assigned to the SOUP treatment, and received a visit from the field agent to collect savings, just as in the GUP with savings group, but did not receive any other components of the program.

The fourth treatment variation was introduced at the household level within the SOUP villages: match versus no match. Of the $59 \%$ of households assigned to treatment, half received savings accounts and deposit collection without a match ("SOUP without match") and half received savings accounts and deposit collection with a 50\% match ("SOUP with match"). Specifically, for every GHC 1 deposited, households in this group received a matching contribution of GHC $0.50 .{ }^{9}$ The remaining households in SOUP villages were assigned to the SOUP control group.

Appendix Table 2 presents the experimental arms and sample sizes for each arm, and Appendix Table 3 clarifies the program components for each of the experimental arms.

\subsection{Data Collection}

We conducted a household survey at baseline, at two years (conducted shortly after the end of the household visits, two years after the assets were transferred and training conducted), and at three years. While the majority of the intervention took place in the first month of the program (the technical training and the productive asset transfer), the household visits and savings collection aspect of the intervention lasted two years. We conducted three additional short midline surveys after six months, one year, and one and a half years; we include the latter two in our two-year analysis. We do not have a baseline survey for the asset-only treatment arm because at the time of starting the project it was not clear we had the funding to implement that arm. Thus we did include the village in the village level randomization, so as to preserve the option for including the treatment arm, but we did not conduct household-level baseline surveys.

Most measures were collected during the aforementioned household surveys with the primary respondent in the household (typically the female head). However, the health, mental health, political, time use, and gender measures were collected in a separate "adult" survey, typically administered to one

\footnotetext{
${ }^{9}$ At the onset of the program, there was a maximum match of GHC $1.50 \mathrm{GHC}$ per week (for a GHC 3 deposit) but this cap was eventually removed.
} 
adult household member. Respondents were asked about the health of all household members, but only about his or her own mental health, political involvement, time use, and gender norms. We pool all of the data that we have for each indicator, which explains much of the variation for number of observations across regressions. See Appendix Table 4 for attrition and the number of observations by survey round.

\subsection{Integrity of the Experiment Design}

Appendix Table 5 provides descriptive statistics for key baseline indicators across treatment arms. Although no systematic pattern emerges, we reject the joint null hypothesis of orthogonality for three out of 14 variables. In analysis, we will show results with and without controls for baseline variables, and in each primary analysis table we report the $p$-value for the difference at baseline for each outcome variable (labelled "bsl p-value").

\subsection{Analysis Methods}

Unless otherwise specified, in all regressions the omitted group is all control households, including the control households in treatment villages. For regressions that do not involve the Asset-Only treatment group, we also control for the outcome at baseline, the baseline variables that we used for stratification via a re-randomization procedure (see Banerjee et al. (2015), and the treatment status of a separate but related study (Banerjee et al. 2020) in which we created a cross-cutting short-term employment program (not implemented in the Asset-Only treatment villages). For regressions that include the Asset-Only treatment households (households for which we did not collect baseline data), we also estimate specifications with controls for three key endline variables that we assert are highly unlikely to have changed as a treatment effect from GUP or SOUP: average household age, household size, and whether or not the house has a metal roof. ${ }^{10}$

As mentioned above, there were three midline surveys administered to a (fixed) random subset of households, a survey administered to all households at two years (the end of the program), and a survey administered to all households at three years (a year later). We typically either report "two-year," "threeyear," or "pooled" outcomes, as indicated in each table. Importantly, our two-year outcomes are an average of the outcome measured at two years and the outcomes measured in the two midline surveys administered within the 12 months prior to the two-year survey. For all regressions that involve survey data, we include interviewer fixed effects, and fixed effects for whether or not the household was surveyed in each midline. When we do pool two-year and three-year outcomes, we include a fixed effect for the survey timing.

\footnotetext{
${ }^{10}$ At the time of the two-year survey the Asset-Only households are $18.5 \%$ smaller than the control households (shown in Appendix Figure 1). Unfortunately, because the Asset-Only treatment was decided upon after the baseline was completed (due to logistics), we have no baseline measure of family size for Asset-Only households. We can however look at how household size changes in GUP and SOUP, since there we have baseline values. We find no evidence of a significant change in SOUP households, but GUP households show a small but significant increase after controlling for any baseline differences between them and the corresponding control households (Appendix Table 6). This fits with our expectations: these households are richer and probably need more labor, hence growth is plausible. Based on this, we would expect the treatment effect of Asset-Only on household size to also be positive though perhaps smaller. We therefore infer that the negative household size difference in the asset-only group between treatment and control is a pre-existing difference and not a treatment effect, and therefore control for it in our regressions.
} 
The most common specification that we use is the following; any deviations from this specification or additional details will be reported in table notes.

$$
Y_{i t}^{k}=\alpha+\beta T_{i}+\gamma Z_{i}^{k}+W_{i}^{\text {strat }}+V_{i}^{\text {short survey }}+\theta_{i t}^{\text {interviewer }}+\varphi_{t}+\left[\mu_{e m p}\right]+\epsilon_{i t}
$$

Where $Y_{i t}^{k}$ is outcome $k$ for individual $i$ at time $t$ (where $\mathrm{t}$ is either two years or three years), $T_{i}$ is a treatment dummy, $Z_{i}^{k}$ is the baseline value of outcome $\mathrm{k}$ for individual $\mathrm{i}, W_{i}^{\text {strat }}$ is a vector of controls that consists of the variables we used for re-randomization, $V_{\text {short survey }}$ is a vector of dummies for whether or not the household was surveyed in each midline, $\theta_{i t}^{\text {interviewer }}$ are interviewer fixed effects, and $\varphi_{t}$ is a dummy that is equal to 1 if the outcome was measured at three years. In addition we include $\mu_{e m p}$, a vector of controls for the employment program treatment arms.

We use the Benjamini-Hochberg step-up method (Benjamini and Hochberg 1995) and procedures put forward in Anderson (2008) to compute q-values that correct for the multiple hypotheses within each table (and sometimes within panels). We do not extend these corrections beyond the boundary of an individual table (or panel) because the substantive aspects of the hypotheses we test change dramatically across tables. ${ }^{11}$ We organize the results by theoretically related hypotheses, which is reflected in the way our tables (panels) are structured. In each case we report the corresponding $p$ - and q-values.

\section{Results}

We begin by looking at final indicators of impact and how they change over time (Section 4.1). Then we examine intermediate outcomes to unpack the differences in effects between the GUP treatment and the SOUP and Asset-Only treatments (Section 4.2). In both sections, to pick up the marginal effect of the additional GUP interventions, we pay special attention to the differences in impacts between GUP with savings and SOUP, and between the Asset-Only intervention and GUP without savings.

\subsection{Impacts}

Table 1 presents estimates of treatment effects on five indices that capture economic wellbeing two years after the productive asset transfer (i.e., two years after the start of the program, and shortly after the end of the household visits). Table 2 presents estimates of the same outcomes three years after the productive asset transfer. These indices are standardized with respect to baseline values; the components are listed in Appendix: Variable Definitions and Construction.

At two years, GUP without savings shows statistically and economically significant effects on asset value, consumption, food security, and income; at three years (a year later), all of these effects persist and an effect on financial inclusion emerges as well. In Appendix Table 7 we show that the effects on financial inclusion is driven by an increase in self-reported savings balances. Thus, even GUP households without deposit collection services manage to save more than control households. GUP with savings shows significant short-run effects on financial inclusion and income, both of which persist a year later, at which time an effect on asset value also emerges. In summary, with or without savings, GUP has long-run effects on income, assets, and financial inclusion; and without savings, it generates long-run consumption effects

\footnotetext{
${ }^{11}$ The boundaries of a set of tests over which one might correct for multiple hypotheses is arbitrary unless one takes a full Bayesian approach.
} 
as well. The point estimate for the consumption index is 0.12 for GUP without savings and 0.05 for GUP with savings ( $p$-value on difference across coefficients is 0.07 ). The lower impact on consumption could be a by-product of consumption being diverted into savings, for future consumption, durables or investment, but is also borderline statistically significant and thus we do not emphasize this comparison.

SOUP has a positive effect on consumption and financial inclusion at two-years; at three-years, the consumption effect disappears and the financial inclusion effect shrinks (and is no longer statistically significant once we account for multiple hypotheses). The positive two-year effects seem driven by higher savings balances. Appendix Table 7 shows that at two years SOUP participants have more than three times the savings balances as control participants; at three years the effect is smaller, with balances less than double those of control. Thus while SOUP does have important short-run impacts, they do not persist after the intervention and deposit-collecting visits to households end, thus in the long-run we observe no substantial changes in household welfare. ${ }^{12}$

Critically, the Asset-Only treatment effects at both two years (Table 1, Panel B) and three years (Table 2, Panel B) are null for all five indices of economic wellbeing. We discuss below potential mechanisms behind this null effect.

We find only a few effects of GUP, SOUP and the Asset-Only treatment arms on secondary outcomes (physical health, mental health, political involvement, labor supply, and female empowerment). After two-years, there are only four effects that come close to surviving multiple hypothesis correction (Appendix Table 10 and 11): GUP with savings on political involvement, GUP without savings on mental health, Asset-Only on mental health (negative), and Asset-Only on time working. None of these effects persists to the three-year measurement-indeed, the effect of Asset-Only on mental health appears to turn positive (but is not statistically significant after adjusting for multiple hypotheses). Overall, there is no evidence that these downstream impacts sustained to three years from any of the individual treatments (although note that in Banerjee et al. (2015), which uses data from multiple sites, downstream results do persist at three years from the full graduation program).

\subsection{Unpacking the Effects}

\subsubsection{Unpacking sources of income}

With or without the savings component, GUP has persistent effects on income: the effect of having any GUP treatment is 0.223 standard deviations (se=0.063), and the effects are similar for both the GUP with savings and GUP without savings treatment arms. Table 3 examines the source of these three-year effects. ${ }^{13}$ It appears that the GUP program boosted income from all three of the activities that are most profitable among control households: crops, businesses, and animals, although only animal revenue effects survive multiple hypothesis correction. Table 3, Column 1 suggests that for GUP with savings, this higher income may be driven in part by the creation of new businesses (though again this effect does not survive the multiple hypothesis correction). GUP households, irrespective of the inclusion of the savings treatment, were seemingly able to build or grow businesses, improve the profitability of their farms, and generate revenues from livestock as a result of the program (Columns 1-4, the differences between the

\footnotetext{
12 In Appendix Tables 8-9, we report two- and three-year estimates, respectively, of differences between SOUP and SOUP match, and GUP and GUP with savings.

${ }^{13}$ Appendix Table 12 reports the corresponding two-year results.
} 
GUP no savings and GUP with savings coefficients are small, and the estimates for "Any GUP" are all statistically significant).

Why did income rise for GUP households and not for households in the SOUP or Asset-Only treatments? In Section 4.2.2 we take a closer look at SOUP households, and in Section 4.2.3 we turn to Asset-Only households.

\subsubsection{Unpacking the savings process, using transaction data}

In Figure 1 we look at the weekly data from our savings collectors, which is, by its very nature, restricted to treatments where there was a savings intervention. We therefore use the pure savings treatment (SOUP no match) as the comparison group. The average SOUP no match household deposited USD 1 in a week on average; this effect rose $9 \%$ in the presence of a match, and more than doubled in the presence of GUP. GUP savings participants save much more during the lean season, which could be because they received consumption support during this time (the savings collector was also the individual responsible for bringing them the cash they received as consumption support, so they could immediately save the cash if they wished).

In Appendix Table 7, columns 1-3, we look at the impact of the program over the long run using the deposits data, again using SOUP no match as the comparison group. In column 4, we look at self-reported savings balances from the two-year household survey, conducted between 1-3 months after the end of savings collection, and in column 5 we look at the same outcome a year later. Here, we use control households as the comparison group (since we have these data for the full sample) in order to look at the effects of SOUP (match and no-match) and GUP (saving and no-savings) on savings balances. Households in GUP savings both deposit much more and take out much more than both the SOUP no-match recipients and the SOUP match recipients, and by the end of the program they have $88 \%$ more in the "bank" than either group. The match has no additional effect on balances, a fact that is consistent with the selfreported data (Appendix Tables 8 and 9). The fourth column of Appendix Table 7 also confirms that the GUP no-savings intervention approximately doubles balances relative to the control group, the SOUP treatments triple it, and GUP savings raises it more than fivefold. ${ }^{14}$ At three years, the treatment effect for GUP no-savings has remained the same (double the control group), and the other treatment arms still generate positive effects but are smaller in magnitude.

The main takeaway seems to be that the availability of savings collectors matters a lot, but the rate of return on savings less so. There also seems to be an income effect-GUP by itself almost doubles savings, even in the absence of savings collectors. There is also an interaction effect between income and savings collection services - at two years GUP savings households save USD 12.9 more than the sum of the independent treatments of GUP no-savings and SOUP no-match, a difference that is statistically significant at the $1 \%$ level $(p=0.003)$.

\footnotetext{
${ }^{14}$ The self-reported savings balance data do not match precisely with the transaction data, as demonstrated by the differences between columns Appendix Table 7 columns 3 and 4 . Note that the survey data were collected between one and three months after the end of the transaction data, thus some of the discrepancy could be due to withdrawals in that period; but no doubt some of this is also due to accuracy challenges when collecting self-reported savings data. The difference is consistent across all three treatment groups for which we have transaction data.
} 


\subsubsection{Unpacking the livestock effect}

In Table 4 we compare GUP no-savings with the Asset-Only treatment to pinpoint the differences in asset accumulation that they generate. The main difference between the two treatments was the combination of handholding and consumption support, both of which were intended to encourage the recipient to further invest in the asset rather than consume it. The handholding both provided knowhow on how to take care of the asset (such as when to vaccinate it, given that goats were the most commonly chosen asset by GUP households) and nudges to help the household to focus on building productive assets to generate positive change in long-term outcomes. The consumption support was explicitly intended to help this process in the short-run, by helping to absorb short-run shocks that could lead to households consuming the transferred assets.

The question of interest here is whether there are differences in the investment patterns. In Table 4 we report livestock value, pooling two-year and three-year results. In column 1 we see that both treatments significantly raise the value of goats owned by the household, though the effect of GUP is higher by \$34. This is despite the fact that, unlike the Asset-Only treatment, not at all GUP households had received goats - they were given a choice between several asset bundles that included goats, fowl, pigs, inputs for maize farming, inputs for rice farming, inputs for sorghum farming, and inputs to begin a shea-butter business. It seems that the GUP households were better at holding onto or growing their goats. ${ }^{15}$ GUP households also accumulate more fowl, which makes sense since many of them chose an asset bundle that included fowl.

Asset-only households do not accumulate any other livestock apart from goats, and indeed appear to have reduced the number of sheep, though this effect does not survive the multiple hypothesis correction. The point estimate on cow value is negative as well. Ultimately, GUP without savings increases the total value of livestock by $\$ 149$ more than the Asset-Only intervention without controls and by $\$ 137$ with controls.

Thus, it seems that graduation households were able to use the additional training and consumption support to accumulate more goats while keeping other livestock as well. This explains why GUP produced sustained effects on assets and animal revenue, and may also have contributed to the rise in business income, by enabling households to undertake riskier projects and investments. ${ }^{16}$

\section{Cost-Benefit Analysis}

Our results thus far suggest that neither savings nor assets alone are sufficient to produce the kinds of persistent impacts on assets, income, and financial inclusion that the full graduation program was able to generate. However, the graduation program cost USD 288 per capita, while the SOUP and Asset-Only programs cost only about $15 \%$ of this amount, at USD 40 per capita. Which of these programs are ultimately cost-effective, if any at all?

In Table 5 we examine the cost-effectiveness of the three programs, taking point estimates from Appendix Tables 15, 16, and 17, which show effects on the values of nondurable consumption and assets, both per

\footnotetext{
15 In Appendix Table 13 we look at the flows of goats between rounds conditional on owning goats in the current round, and find that GUP households have more goat births and sales than Asset-Only. We cannot construct stock estimates from the flows, in part because we only collected flow data for households that owned at least one goat at the time of each survey.

${ }^{16}$ In Appendix Table 14 we examine productive assets, household assets, and agricultural stocks, but find no GUP treatment effect on productive assets. The impact on assets is driven entirely by livestock.
} 
capita and per household. For the Asset-Only households we do not have data from the first year, so we run two versions of the analysis: one where we assume that year-one effects were the same as year-two effects, and another where we assume that year-one effects were equal to the value of the asset transferred. We then assume that three-year effects persist in perpetuity, assuming a $5 \%$ annual discount rate (a defendable assumption, given the evidence from elsewhere on the long-term persistence of the results).

Ultimately we find that the ratio of benefits to costs is 1.21 for the graduation program. For the SOUP and Asset-Only programs (under the assumption that year-one effects were equal to the year-two effects), we actually have negative ratios due to slightly negative point estimates. However these negative estimates are not statistically different from zero, nor are they robust to a specification that uses per household, rather than per capita measures, as evidenced by column 2 of Appendix Table 16. We thus interpret the benefit-cost ratios for SOUP and Asset-Only as effectively zero. Thus, even when the high costs of GUP are taken into account, the program is cost-effective; and even when the low costs of SOUP and Asset-Only are taken into account, they are not worthwhile.

\section{Discussion}

While earlier work (Banerjee et al. 2015; Bandiera et al. 2017) found that a multi-faceted program was sufficient for generating economically meaningful and sustainable impacts for those in extreme poverty, the analysis did not establish whether the multi-faceted approach was necessary. Here we show that neither transferring a productive asset (in this case, goats) nor providing access to a savings account, on their own, generate similar economically meaningful and sustainable impacts in the same population. This is a critical finding: identifying simpler programs, i.e. ones with reduced implementation complexity and lower costs, that work would be ideal as one plans for a nationwide social protection policy.

Many questions remain that are important both for understanding more about the underlying mechanisms of poverty traps, and for forming the optimal policy for social protection at scale. For example, cash transfers are a natural alternative (because of lower transaction costs, lower probability of moving prices when implemented at scale, and higher flexibility the cash affords the recipient to choose their own investment). However cash transfers also have been shown to be less likely to be invested (Fafchamps et al. 2014). Lump-sum cash transfers do better than constant smaller streams of cash flow for encouraging investment (rather than immediate consumption), but still much of the funds get used for durable consumption goods, such as home improvements (Haushofer and Shapiro 2016). These may generate long-term benefits for households, but perhaps not higher long-term income. More is needed to understand whether cash transfers implemented in other locations or alongside some form of behavioral intervention, e.g. a "nudge" in which individuals form a simple non-binding plan before receiving the cash, would lead to higher levels of investment and thus longer term impact on income.

The household visits serve multiple roles, including providing information and behavioral support. At scale, these pose a real challenge, as they require a vast network of field agents who are both well informed about the range of productive assets that might be transferred to help households when problems arise, and also well versed in how to engage households in life coaching, to help build hope and encourage the aspirations of the households and guide them to stay on track with a long term plan of building productive assets. Some have suggested technological solutions to this problem, for example a mobile device that provides videos with information and mobile applications which facilitate 
communication between households and field agents (for example, that generate a regular stream of text messages at predefined or appropriately triggered times). Such a technology may make it easier to implement the program at scale without losing implementation fidelity, yet may put at risk the impact if direct human interaction is necessary.

On the other hand, perhaps rather than looking for components to shed, an even richer program would be more effective. Despite the success on average, not everyone benefits from the program. Those in extreme poverty suffer from high levels of depression (Sipsma et al. 2013). Perhaps those with poor mental health are not able to embrace the opportunity fully, and thus a mental health intervention that precedes the multi-faceted program would generate even bigger impacts. Among a highly selected population of youth engaged in street crime in Liberia, cognitive behavioral therapy in conjunction with cash has led to important positive economic changes a year later (Blattman, Jamison, and Sheridan 2015).

In Ghana, this is now being tested in a new sample frame of ultra-poor households similar to the population studied here.

\section{References}

Anderson, Michael. 2008. "Multiple Inference and Gender Differences in the Effects of Early Intervention: A Reevaluation of the Abecedarian, Perry Preschool, and Early Training Projects." Journal of the American Statistical Association 103 (484): 1481-95. https://doi.org/10.1198/016214508000000841.

Attanasio, Orazio, Adriana Kugler, and Costas Meghir. 2011. "Subsidizing Vocational Training for Disadvantaged Youth in Colombia: Evidence from a Randomized Trial." American Economic Journal: Applied Economics 3 (3): 188-220.

Balboni, Clare, Oriana Bandiera, Robin Burgess, Maitreesh Ghatak, and Anton Heil. 2020. "Why Do People Stay Poor?" Working Paper, March. https://www.dropbox.com/s/4tfuhclfvh6ynnd/povertyTraps.pdf?dl=0.

Bandiera, Oriana, Robin Burgess, Narayan Das, Selim Gulesci, Imran Rasul, and Munshi Sulaiman. 2017. "Labor Markets and Poverty in Village Economies." The Quarterly Journal of Economics 132 (2): 811-70. https://doi.org/10.1093/qje/qjx003.

Banerjee, Abhijit, Emily Breza, Esther Duflo, and Cynthia Kinnan. 2019. “Can Microfinance Unlock a Poverty Trap for Some Entrepreneurs?" SSRN Scholarly Paper ID 3465363. Rochester, NY: Social Science Research Network. https://papers.ssrn.com/abstract=3465363.

Banerjee, Abhijit, Esther Duflo, Raghabendra Chattopadhyay, and Jeremy Shapiro. 2016. "Long Term Impact of a Livelihood Intervention: Evidence from West Bengal." Working Paper.

Banerjee, Abhijit, Esther Duflo, Nathanael Goldberg, Dean Karlan, Robert Osei, William Parienté, Jeremy Shapiro, Bram Thuysbaert, and Christopher Udry. 2015. "A Multifaceted Program Causes Lasting Progress for the Very Poor: Evidence from Six Countries." Science 348 (6236): 1260799. https://doi.org/10.1126/science.1260799.

Banerjee, Abhijit, Dean Karlan, Hannah Trachtman, and Christopher Udry. 2020. "Does Poverty Change Labor Supply? Evidence from Multiple Income Effects and 115,579 Bags." Working Paper.

Banerjee, Abhijit, Dean Karlan, and Jonathan Zinman. 2015. "Six Randomized Evaluations of Microcredit: Introduction and Further Steps." American Economic Journal: Applied Economics 7 (1): 1-21.

Bausch, et al. 2016. "The Impact of Skills Training on Financial Behaviour, Employability, and Educational Choice of Youth in Morocco."

Benjamini, Yoav, and Yosef Hochberg. 1995. "Controlling the False Discovery Rate: A Practical and Powerful Approach to Multiple Testing." Journal of the Royal Statistical Society. Series $B$ (Methodological), 289-300. 
Berge, Lars, Kjetil Bjorvatn, and Bertil Tungooden. 2014. "Human and Financial Capital for Microenterprise Development: Evidence from a Field and Lab Experiment." Management Science forthcoming.

Blattman, Christopher, Nathan Fiala, and Sebastian Martinez. 2014. "Generating Skilled SelfEmployment in Developing Countries: Experimental Evidence from Uganda." The Quarterly Journal of Economics 129 (2): 697-752.

Blattman, Christopher, Eric P Green, Julian Jamison, M Christian Lehmann, and Jeannie Annan. 2016. "The Returns to Microenterprise Support among the Ultrapoor: A Field Experiment in Postwar Uganda." American Economic Journal: Applied Economics 8 (2): 35-64.

Blattman, Christopher, Julian Jamison, and Margaret Sheridan. 2015. "Reducing Crime and Violence: Experimental Evidence on Adult Noncognitive Investments in Liberia."

Bloom, Nicholas, Benn Eifert, Aprajit Mahajan, David McKenzie, and John Roberts. 2012. "Does Management Matter? Evidence from India." The Quarterly Journal of Economics, November, qjs044. https://doi.org/10.1093/qje/qjs044.

Breza, Emily, and Cynthia Kinnan. 2018. "Measuring the Equilibrium Impacts of Credit: Evidence from the Indian Microfinance Crisis." Working Paper.

Bruhn, Miriam, Dean Karlan, and Antoinette Schoar. 2018. "The Impact of Consulting Services on Small and Medium Enterprises: Evidence from a Randomized Trial in Mexico." Journal of Political Economy forthcoming.

Drexler, Alejandro, Greg Fischer, and Antoinette Schoar. 2014. "Keeping It Simple: Financial Literacy and Rules of Thumb." American Economic Journal: Applied Economics 6 (2): 1-31. https://doi.org/10.1257/app.6.2.1.

Duflo, Esther. 2001. "Schooling and Labor Market Consequences of School Construction in Indonesia: Evidence from an Unusual Policy Experiment." American Economic Review 91 (4): 795-813. https://doi.org/10.1257/aer.91.4.795.

Duflo, Esther, Pascaline Dupas, and Michael Kremer. 2017. "The Impact of Free Secondary Education: Experimental Evidence from Ghana." Working Paper.

Dupas, Pascaline, Dean Karlan, Jonathan Robinson, and Diego Ubfal. 2017. "Banking the Unbanked? Evidence from Three Countries." American Economic Journal: Applied Economics forthcoming. https://doi.org/10.1257/app.20160597.

Fafchamps, Marcel, David McKenzie, Simon Quinn, and Christopher Woodruff. 2014. "Microenterprise Growth and the Flypaper Effect: Evidence from a Randomized Experiment in Ghana." Journal of Development Economics 106 (January): 211-26. https://doi.org/10.1016/j.jdeveco.2013.09.010.

Gertler, Paul J, Sebastian W Martinez, and Marta Rubio-Codina. 2012. "Investing Cash Transfers to Raise Long-Term Living Standards." American Economic Journal: Applied Economics 4 (1): 164-92.

Giné, Xavier, and Ghazala Mansuri. 2011. "Money or Ideas? A Field Experiment on Constraints to Entrepreneurship in Rural Pakistan."

Haushofer, Johannes, and Jeremy Shapiro. 2016. "The Short-Term Impact of Unconditional Cash Transfers to the Poor: Experimental Evidence from Kenya." Quarterly Journal of Economics 131 (4).

Karlan, Dean, Ryan Knight, and Christopher Udry. 2015. "Consulting and Capital Experiments with Microenterprise Tailors in Ghana." Journal of Economic Behavior \& Organization, Economic Experiments in Developing Countries, 118 (October): 281-302. https://doi.org/10.1016/j.jebo.2015.04.005.

Karlan, Dean, Robert Osei, Isaac Osei-Akoto, and Christopher Udry. 2014. "Agricultural Decisions after Relaxing Credit and Risk Constraints." The Quarterly Journal of Economics 129 (2): 597-652. https://doi.org/10.1093/qje/qju002. 
Karlan, Dean, Beniamino Savonitto, Bram Thuysbaert, and Christopher Udry. 2017. "Impact of Savings Groups on the Lives of the Poor." Proceedings of the National Academy of Sciences 114 (12): 3079-84. https://doi.org/10.1073/pnas.1611520114.

Kugler, Adriana, Maurice Kugler, Juan Saavedra, and Luis Omar Herrera Prada. 2015. "Long-Term Direct and Spillover Effects of Job Training: Experimental Evidence from Colombia." Working Paper 21607. National Bureau of Economic Research. https://doi.org/10.3386/w21607.

McKenzie, David, and Christopher Woodruff. 2014. "What Are We Learning from Business Training and Entrepreneurship Evaluations around the Developing World?" The World Bank Research Observer 29 (1): 48-82. https://doi.org/10.1093/wbro/lkt007.

Meager, Rachael. 2018. "Aggregating Distributional Treatment Effects: ABayesian Hierarchical Analysis of the MicrocreditLiterature." LSE Working Paper.

- - . 2019. "Understanding the Average Impact of Microcredit Expansions: A Bayesian Hierarchical Analysis of Seven Randomized Experiments." American Economic Journal: Applied Economics 11 (1): 57-91. https://doi.org/10.1257/app.20170299.

Mel, Suresh de, David McKenzie, and Christopher Woodruff. 2008. "Returns to Capital in Microenterprises: Evidence from a Field Experiment." The Quarterly Journal of Economics 123 (4): 1329-72. https://doi.org/10.1162/qjec.2008.123.4.1329.

Sipsma, Heather, Angela Ofori-Atta, Maureen Canavan, Isaac Osei-Akoto, Christopher Udry, and Elizabeth H Bradley. 2013. "Poor Mental Health in Ghana: Who Is at Risk?" BMC Public Health 13 (1): 288. 
Figure 1: Monthly Deposits (for Treatment Groups with Savings Component)

(a)

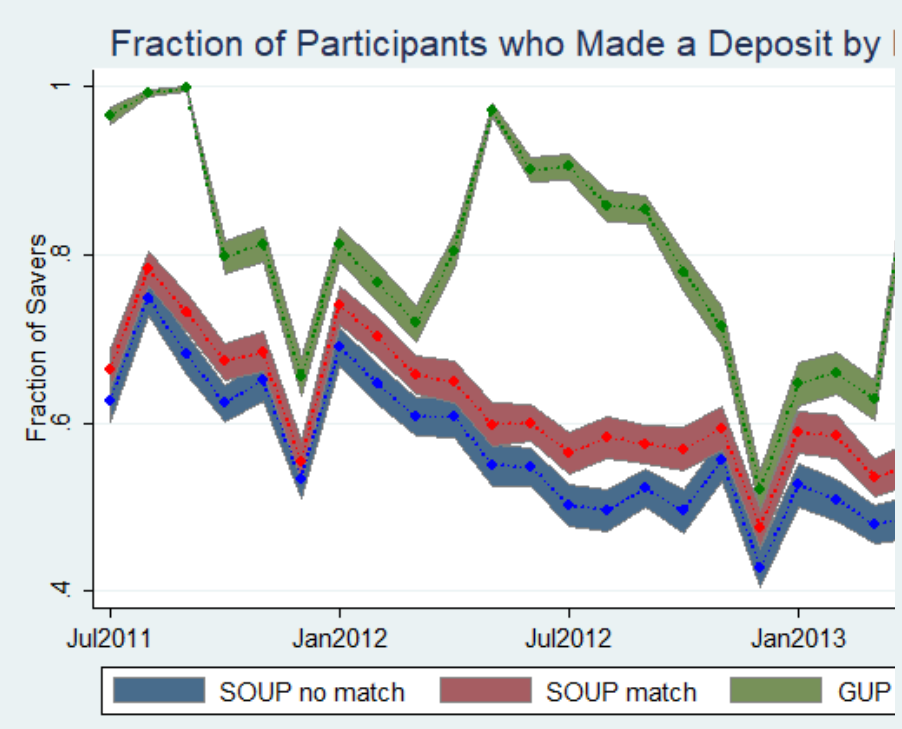

(b)

Deposits (USD) by Month

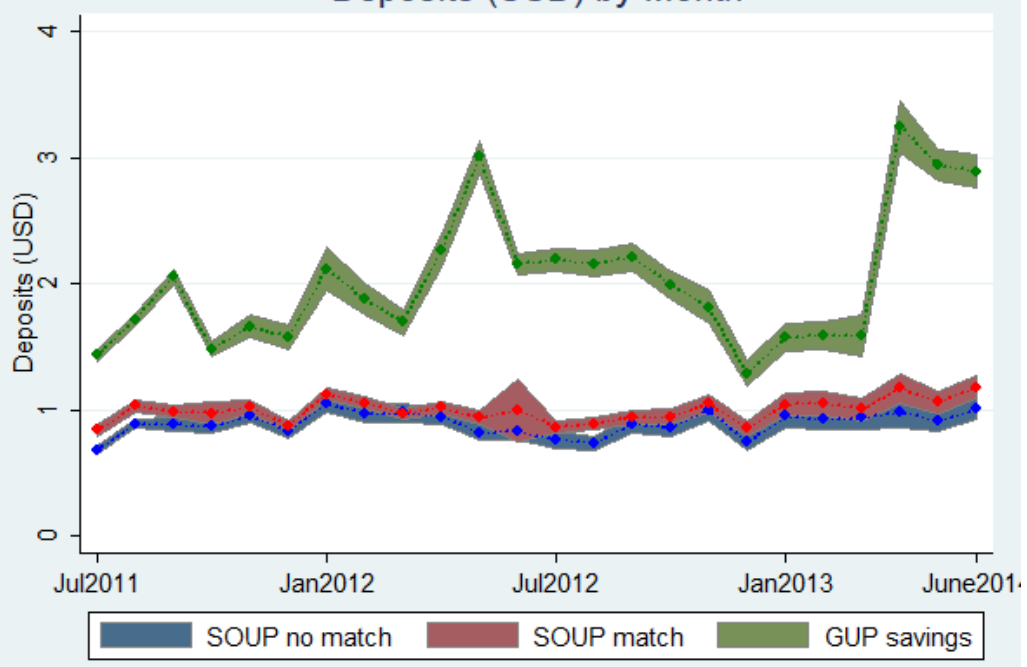

(c)

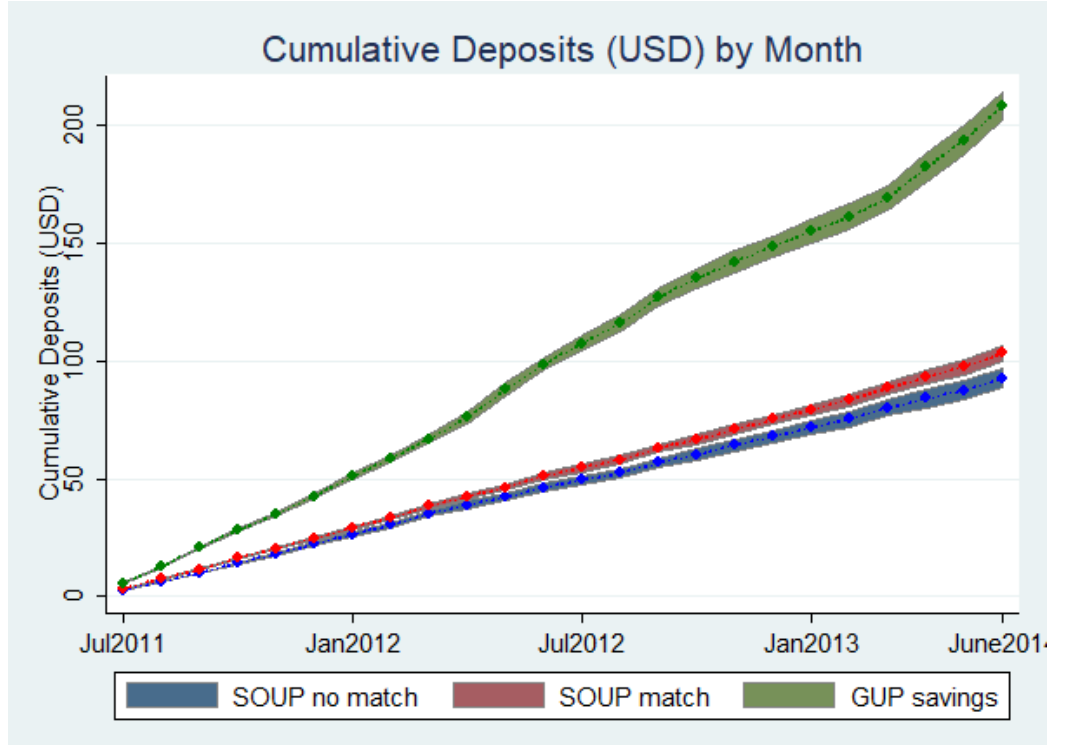


Table 1: Two-Year Effects of GUP, SOUP, and Asset Only on Household-Level Economic Indices

\begin{tabular}{|c|c|c|c|c|c|c|}
\hline & & $\begin{array}{l}(1) \\
\text { asset value } \\
\text { index }\end{array}$ & $\begin{array}{c}(2) \\
\text { consumption } \\
\text { index }\end{array}$ & $\begin{array}{c}(3) \\
\text { financial } \\
\text { inclusion index }\end{array}$ & $\begin{array}{c}(4) \\
\text { food security } \\
\text { index }\end{array}$ & $\begin{array}{c}(5) \\
\text { income index }\end{array}$ \\
\hline \multicolumn{7}{|c|}{ PANEL A: GUP vs. SOUP } \\
\hline \multirow[t]{5}{*}{ SOUP } & itt & 0.112 & 0.138 & 0.497 & 0.056 & 0.064 \\
\hline & se & $(0.068)$ & $(0.043)$ & $(0.093)$ & $(0.043)$ & $(0.050)$ \\
\hline & p-val & $0.097^{*}$ & $0.001^{* * *}$ & $0.000^{* * *}$ & 0.185 & 0.200 \\
\hline & q-val & 0.163 & $0.007^{* * *}$ & $0.001^{* * *}$ & 0.285 & 0.286 \\
\hline & bsl p-val & $0.051^{*}$ & 0.993 & 0.555 & $0.098^{*(+)}$ & 0.277 \\
\hline \multirow[t]{5}{*}{ GUP no sav. } & itt & 0.228 & 0.141 & 0.172 & 0.104 & 0.138 \\
\hline & se & $(0.072)$ & $(0.051)$ & $(0.098)$ & $(0.049)$ & $(0.054)$ \\
\hline & p-val & $0.002^{* * *}$ & $0.006^{* * *}$ & $0.080^{*}$ & $0.035^{* *}$ & $0.011^{* *}$ \\
\hline & q-val & $0.007^{* * *}$ & $0.022^{* *}$ & 0.163 & $0.088^{*}$ & $0.033^{* *}$ \\
\hline & bsl p-val & 0.741 & $0.022^{* *}$ & $0.014^{* *}$ & 0.282 & 0.205 \\
\hline \multirow[t]{5}{*}{ GUP sav. } & itt & 0.110 & 0.084 & 1.247 & -0.017 & 0.206 \\
\hline & se & $(0.066)$ & $(0.050)$ & $(0.142)$ & $(0.047)$ & $(0.056)$ \\
\hline & p-val & $0.095^{*}$ & $0.091^{*}$ & $0.000 * * *$ & 0.722 & $0.000^{* * *}$ \\
\hline & q-val & 0.163 & 0.163 & $0.001^{* * *}$ & 0.855 & $0.002^{* * *}$ \\
\hline & bsl p-val & 0.592 & 0.100 & 0.632 & 0.704 & 0.794 \\
\hline \multirow[t]{4}{*}{ GUP sav. - SOUP } & diff & -0.002 & -0.054 & 0.750 & -0.073 & 0.142 \\
\hline & se & $(0.085)$ & $(0.061)$ & $(0.169)$ & $(0.058)$ & $(0.070)$ \\
\hline & p-val & 0.982 & 0.378 & $0.000^{* * *}$ & 0.210 & $0.042^{* *}$ \\
\hline & bsl p-val & 0.240 & 0.176 & 0.426 & 0.138 & 0.353 \\
\hline \multirow[t]{5}{*}{ any GUP } & itt & 0.168 & 0.112 & 0.714 & 0.043 & 0.172 \\
\hline & & $(0.059)$ & $(0.044)$ & $(0.099)$ & $(0.042)$ & $(0.047)$ \\
\hline & p-val & $0.005^{* * *}$ & $0.011^{* *}$ & $0.000^{* * *}$ & 0.301 & $0.000^{* * *}$ \\
\hline & bsl p-val & 0.624 & $0.025^{* *}$ & 0.103 & 0.390 & 0.378 \\
\hline & obs & 3801 & 3707 & 3708 & 3708 & 3800 \\
\hline \multicolumn{7}{|c|}{ PANEL B: GUP vs. Asset Only } \\
\hline \multirow[t]{7}{*}{ asset } & itt & -0.082 & -0.019 & 0.031 & -0.015 & 0.007 \\
\hline & se & $(0.115)$ & $(0.074)$ & $(0.095)$ & $(0.062)$ & $(0.060)$ \\
\hline & p-val & 0.477 & 0.801 & 0.747 & 0.812 & 0.908 \\
\hline & q-val & 0.636 & 0.855 & 0.855 & 0.855 & 0.908 \\
\hline & itt, ctrls & -0.075 & -0.007 & 0.032 & -0.009 & 0.009 \\
\hline & p-val, ctrls & 0.511 & 0.923 & 0.735 & 0.887 & 0.877 \\
\hline & q-val, ctrls & 0.924 & 0.924 & 0.924 & 0.924 & 0.924 \\
\hline \multirow[t]{6}{*}{ GUP no sav. - asset } & diff & 0.326 & 0.124 & 0.124 & 0.113 & 0.140 \\
\hline & se & $(0.141)$ & $(0.092)$ & $(0.137)$ & $(0.079)$ & $(0.082)$ \\
\hline & p-val & $0.021^{* *}$ & 0.179 & 0.365 & 0.152 & $0.088^{*}$ \\
\hline & itt, ctrls & 0.265 & 0.145 & 0.108 & 0.105 & 0.107 \\
\hline & p-val, ctrls & $0.054^{*}$ & $0.094^{*}$ & 0.432 & 0.185 & 0.191 \\
\hline & obs & 4121 & 4006 & 4007 & 4007 & 4120 \\
\hline
\end{tabular}

Estimates from OLS regressions of household-level economic indices at year two (averaging over two-year outcome and midline outcomes that were collected at least one year after treatment start) on treatments. The omitted group is control households in all villages. The regression in Panel A excludes the asset only villages and includes controls for re-randomization variables and the baseline value of the outcome. The regression in Panel B includes the asset only villages (without baseline controls). Both panels include controls for employment program treatments. We include fixed effects for all villages except those assigned to pure control, and dummies for whether or not the household was surveyed in each midline. Standard errors clustered at unit of randomization (village for pure control, individual otherwise). We use the Benjamini-Hochberg step-up method to compute q-values, considering the 20 independent hypotheses in the table. For regressions that include asset households, we also report p-values and q-values for a specification with three two-year variables as controls, since we have no baseline controls. (See appendix for evidence that these variables were mostly not affected by the GUP or SOUP treatments.) Finally, we report p-values for the same specification using the baseline value of each outcome. We use a superscript $(+)$ to indicate a positive t-statistic. Indices are centered around baseline values. See appendix for detailed descriptions of each variable. 
Table 2: Three-Year Effects of GUP, SOUP, and Asset Only on Household-Level Economic Indices

\begin{tabular}{|c|c|c|c|c|c|c|}
\hline & & $\begin{array}{l}(1) \\
\text { asset value } \\
\text { index }\end{array}$ & $\begin{array}{c}(2) \\
\text { consumption } \\
\text { index }\end{array}$ & $\begin{array}{c}(3) \\
\text { financial } \\
\text { inclusion index }\end{array}$ & $\begin{array}{c}(4) \\
\text { food security } \\
\text { index }\end{array}$ & $\begin{array}{c}(5) \\
\text { income index }\end{array}$ \\
\hline \multicolumn{7}{|c|}{ PANEL A: GUP vs. SOUP } \\
\hline \multirow[t]{5}{*}{ SOUP } & itt & 0.029 & -0.013 & 0.129 & 0.002 & -0.071 \\
\hline & se & $(0.076)$ & $(0.034)$ & $(0.073)$ & $(0.044)$ & $(0.062)$ \\
\hline & p-val & 0.701 & 0.700 & $0.078^{*}$ & 0.962 & 0.254 \\
\hline & q-val & 0.825 & 0.825 & 0.156 & 0.963 & 0.373 \\
\hline & bsl p-val & $0.051^{*}$ & 0.993 & 0.555 & $0.098^{*(+)}$ & 0.277 \\
\hline \multirow[t]{5}{*}{ GUP no sav. } & itt & 0.280 & 0.124 & 0.204 & 0.114 & 0.202 \\
\hline & se & $(0.078)$ & $(0.046)$ & $(0.086)$ & $(0.050)$ & $(0.073)$ \\
\hline & p-val & $0.000^{* * *}$ & $0.007^{* * *}$ & $0.018^{* *}$ & $0.024^{* *}$ & $0.006^{* * *}$ \\
\hline & q-val & $0.003^{* * *}$ & $0.022^{* *}$ & $0.051^{*}$ & $0.059^{*}$ & $0.022^{* *}$ \\
\hline & bsl p-val & 0.741 & $0.022^{* *}$ & $0.014^{* *}$ & 0.282 & 0.205 \\
\hline \multirow[t]{5}{*}{ GUP sav. } & itt & 0.318 & 0.050 & 0.532 & 0.092 & 0.243 \\
\hline & se & $(0.082)$ & $(0.036)$ & $(0.105)$ & $(0.050)$ & $(0.076)$ \\
\hline & p-val & $0.000^{* * *}$ & 0.169 & $0.000 * * *$ & $0.062^{*}$ & $0.001^{* * *}$ \\
\hline & q-val & $0.002^{* * *}$ & 0.282 & $0.001^{* * *}$ & 0.139 & $0.008^{* * *}$ \\
\hline & bsl p-val & 0.592 & 0.100 & 0.632 & 0.704 & 0.794 \\
\hline \multirow[t]{4}{*}{ GUP sav. - SOUP } & diff & 0.289 & 0.063 & 0.402 & 0.090 & 0.314 \\
\hline & se & $(0.105)$ & $(0.046)$ & $(0.122)$ & $(0.063)$ & $(0.094)$ \\
\hline & p-val & $0.006^{* * *}$ & 0.173 & $0.001^{* * *}$ & 0.150 & $0.001^{* * *}$ \\
\hline & bsl p-val & 0.240 & 0.176 & 0.426 & 0.138 & 0.353 \\
\hline \multirow[t]{5}{*}{ any GUP } & itt & 0.299 & 0.088 & 0.366 & 0.103 & 0.223 \\
\hline & & $(0.068)$ & $(0.036)$ & $(0.077)$ & $(0.043)$ & $(0.063)$ \\
\hline & p-val & $0.000^{* * *}$ & $0.015^{* *}$ & $0.000^{* * *}$ & $0.017^{* *}$ & $0.000^{* * *}$ \\
\hline & bsl p-val & 0.624 & $0.025^{* *}$ & 0.103 & 0.390 & 0.378 \\
\hline & obs & 3781 & 3597 & 3603 & 3603 & 3781 \\
\hline \multicolumn{7}{|c|}{ PANEL B: GUP vs. Asset Only } \\
\hline \multirow[t]{7}{*}{ asset } & itt & -0.022 & -0.009 & 0.050 & -0.079 & -0.133 \\
\hline & se & $(0.103)$ & $(0.055)$ & $(0.073)$ & $(0.070)$ & $(0.085)$ \\
\hline & p-val & 0.832 & 0.867 & 0.490 & 0.261 & 0.119 \\
\hline & q-val & 0.913 & 0.913 & 0.654 & 0.373 & 0.218 \\
\hline & itt, ctrls & -0.043 & -0.006 & 0.029 & -0.075 & -0.148 \\
\hline & p-val, ctrls & 0.684 & 0.909 & 0.692 & 0.283 & $0.080^{*}$ \\
\hline & q-val, ctrls & 0.866 & 0.910 & 0.866 & 0.708 & 0.399 \\
\hline \multirow[t]{6}{*}{ GUP no sav. - asset } & diff & 0.325 & 0.114 & 0.154 & 0.188 & 0.345 \\
\hline & se & $(0.135)$ & $(0.073)$ & $(0.113)$ & $(0.086)$ & $(0.114)$ \\
\hline & p-val & $0.016^{* *}$ & 0.116 & 0.172 & $0.029^{* *}$ & $0.002^{* * *}$ \\
\hline & itt, ctrls & 0.288 & 0.123 & 0.160 & 0.178 & 0.319 \\
\hline & p-val, ctrls & $0.032^{* *}$ & $0.091^{*}$ & 0.153 & $0.039^{* *}$ & $0.004^{* * *}$ \\
\hline & obs & 4102 & 3883 & 3893 & 3893 & 4102 \\
\hline
\end{tabular}

Estimates from OLS regressions of household-level economic indices at year two (averaging over two-year outcome and midline outcomes that were collected at least one year after treatment start) on treatments. The omitted group is control households in all villages. The regression in Panel A excludes the asset only villages and includes controls for re-randomization variables and the baseline value of the outcome. The regression in Panel B includes the asset only villages (without baseline controls). Both panels include controls for employment program treatments. We include fixed effects for all villages except those assigned to pure control, and dummies for whether or not the household was surveyed in each midline. Standard errors clustered at unit of randomization (village for pure control, individual otherwise). We use the Benjamini-Hochberg step-up method to compute q-values, considering the 20 independent hypotheses in the table. For regressions that include asset households, we also report p-values and q-values for a specification with three two-year variables as controls, since we have no baseline controls. (See appendix for evidence that these variables were mostly not affected by the GUP or SOUP treatments.) Finally, we report p-values for the same specification using the baseline value of each outcome. We use a superscript $(+)$ to indicate a positive t-statistic. Indices are centered around baseline values. See appendix for detailed descriptions of each variable. 
Table 3: Three-Year Effects of GUP, SOUP, and Asset Only on Income Sources

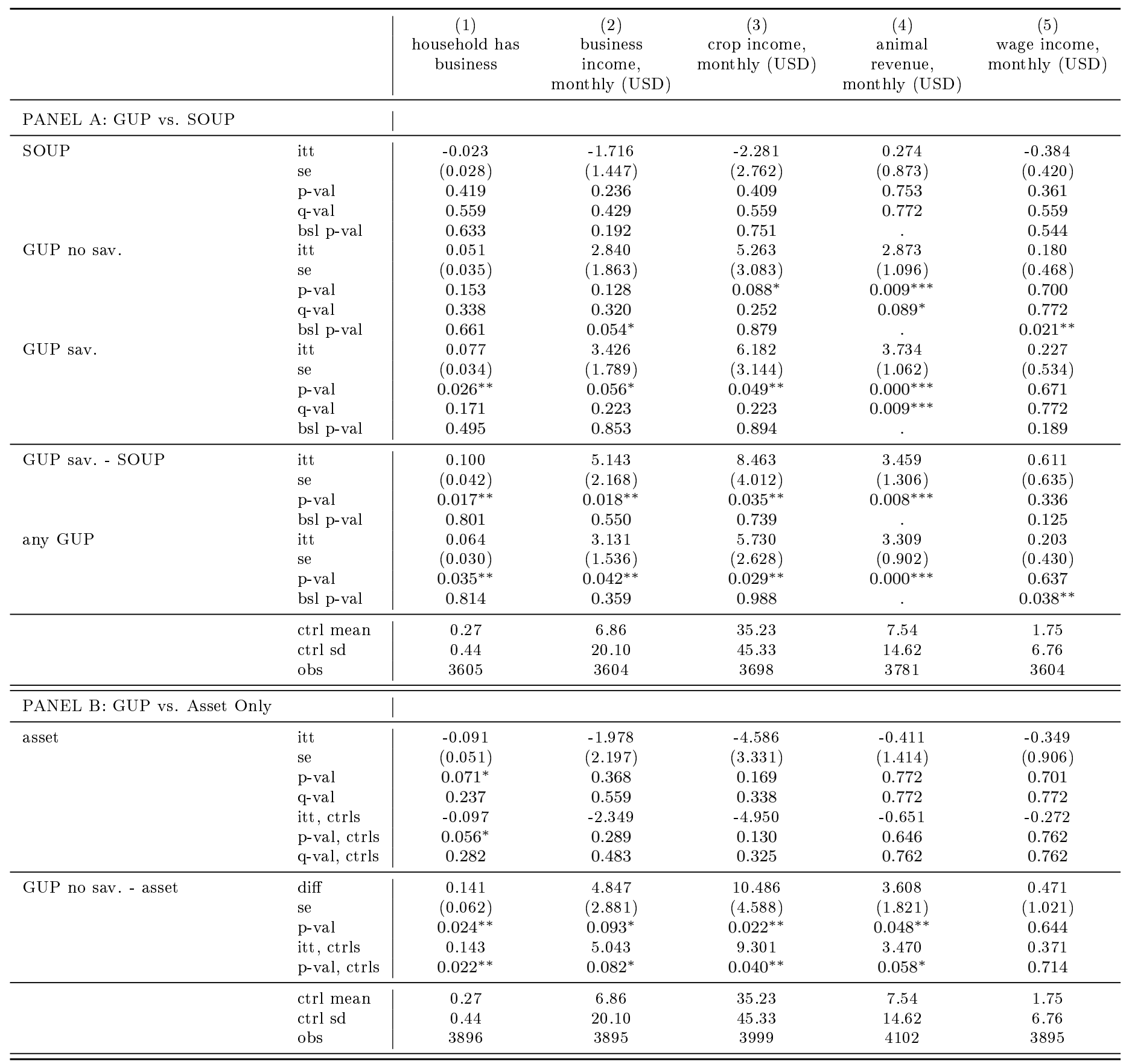

Estimates from OLS regressions of household-level economic indices from year two (averaging over two-year outcome and midline outcomes that were collected at least one year after treatment start) on treatments. The omitted group is control households in control villages. The regression in Panel A excludes the asset only villages and includes controls for re-randomization variables and the baseline value of the outcome. The regression in Panel B includes the asset only villages (without baseline controls). Both panels include controls for employment program treatments.. We also include interviewer fixed effects and fixed effects for whether or not the household was surveyed in each midline. Standard errors clustered at unit of randomization (village for pure control, individual otherwise). We use the Benjamini-Hochberg step-up method to compute q-values, considering the 20 independent hypotheses in the table. For regressions that include asset households, we also report p-values and q-values for a specification with three two-year variables as controls, since we have no baseline controls. (See appendix for evidence that these variables were mostly not affected by the GUP or SOUP treatments.) Finally, we report p-values for the same specification using the baseline value of each outcome. We use a superscript $(+)$ to indicate a positive t-statistic. See appendix for detailed descriptions of each variable. 
Table 4: Pooled Two-Year and Three-Year Effects of GUP and Asset Only on Household-Level Livestock Values

\begin{tabular}{|c|c|c|c|c|c|c|c|}
\hline & & $\begin{array}{c}(1) \\
\text { goat value } \\
\text { (USD) }\end{array}$ & $\begin{array}{c}(2) \\
\text { fowl value } \\
\text { (USD) }\end{array}$ & $\begin{array}{c}(3) \\
\text { pig value } \\
\text { (USD) }\end{array}$ & $\begin{array}{c}(4) \\
\text { sheep value } \\
\text { (USD) }\end{array}$ & $\begin{array}{c}(5) \\
\text { cow value } \\
(\mathrm{USD})\end{array}$ & $\begin{array}{l}(6) \\
\text { total livestock } \\
\text { value (USD) }\end{array}$ \\
\hline \multirow[t]{7}{*}{ GUP no sav. } & itt & 71.511 & 12.527 & 4.550 & 1.377 & 12.975 & 134.776 \\
\hline & se & $(7.984)$ & $(3.722)$ & $(2.002)$ & $(9.006)$ & $(12.953)$ & $(27.636)$ \\
\hline & p-val & $0.000^{* * *}$ & $0.001^{* * *}$ & $0.023^{* *}$ & 0.878 & 0.317 & $0.000^{* * *}$ \\
\hline & q-val & $0.001^{* * *}$ & $0.003^{* * *}$ & $0.056^{*}$ & 0.879 & 0.423 & $0.001^{* * *}$ \\
\hline & itt, ctrls & 68.681 & 11.047 & 4.460 & -2.649 & 10.330 & 120.363 \\
\hline & p-val, ctrls & $0.000^{* * *}$ & $0.003^{* * *}$ & $0.026^{* *}$ & 0.768 & 0.424 & $0.000^{* * *}$ \\
\hline & q-val, ctrls & $0.001^{* * *}$ & $0.009^{* * *}$ & $0.063^{*}$ & 0.769 & 0.512 & $0.001^{* * *}$ \\
\hline \multirow[t]{7}{*}{ asset } & itt & 37.217 & -3.221 & 1.861 & -22.715 & -19.320 & -13.798 \\
\hline & se & $(10.230)$ & $(4.708)$ & $(1.806)$ & $(13.920)$ & $(15.536)$ & $(38.521)$ \\
\hline & p-val & $0.000^{* * *}$ & 0.494 & 0.303 & 0.103 & 0.214 & 0.720 \\
\hline & q-val & $0.002^{* * *}$ & 0.593 & 0.423 & 0.206 & 0.367 & 0.786 \\
\hline & itt, ctrls & 36.178 & -3.799 & 2.372 & -24.377 & -18.285 & -16.406 \\
\hline & p-val, ctrls & $0.000^{* * *}$ & 0.426 & 0.230 & $0.083^{*}$ & 0.215 & 0.665 \\
\hline & q-val, ctrls & $0.002^{* * *}$ & 0.512 & 0.345 & 0.167 & 0.345 & 0.726 \\
\hline \multirow[t]{8}{*}{ GUP no sav. - asset } & diff & 34.294 & 15.748 & 2.690 & 24.092 & 32.296 & 148.574 \\
\hline & se & $(12.978)$ & $(6.007)$ & $(2.705)$ & $(16.596)$ & $(20.199)$ & $(47.433)$ \\
\hline & p-val & $0.008^{* * *}$ & $0.009^{* * *}$ & 0.320 & 0.147 & 0.110 & $0.002^{* * *}$ \\
\hline & itt, ctrls & 32.502 & 14.846 & 2.088 & 21.727 & 28.616 & 136.769 \\
\hline & p-val, ctrls & $0.012^{* *}$ & $0.014^{* *}$ & 0.457 & 0.193 & 0.145 & $0.003^{* * *}$ \\
\hline & ctrl mean & 80.0 & 47.8 & 3.5 & 68.0 & 38.1 & 263.9 \\
\hline & ctrl sd & 115.4 & 60.7 & 21.4 & 149.4 & 198.1 & 475.7 \\
\hline & obs & 8217 & 8222 & 8217 & 8217 & 8217 & 8222 \\
\hline
\end{tabular}

Estimates from OLS regressions of asset-related outcomes on GUP and asset treatments. The omitted group is control households in all villages. We pool outcomes from the two-year (averaging over the two-year outcome and midline outcomes that were collected at least one year after treatment start) and three-year surveys. We control for employment program treatments. We include fixed effects for all villages except those assigned to pure control, dummies for the survey round (two-year or three-year) and dummies for whether or not the household was surveyed in each midline. Standard errors clustered at unit of randomization (village-level for pure control, individual-level otherwise). We use the Benjamini-Hochberg step-up method to compute q-values, considering the 12 independent hypotheses in the table. We also report p-values and q-values for a specification with three two-year variables as controls (average age, metal roof, household size), since we have no baseline controls. See appendix for detailed descriptions of each variable. 
Table 5: Cost Benefit Analysis

\begin{tabular}{|c|c|c|c|}
\hline & GUP & SOUP & Asset Only \\
\hline \multicolumn{4}{|l|}{ COSTS PER CAPITA } \\
\hline Program costs, calculated as if all incurred immediately at beginning of year 0 & $\$ 288$ & $\$ 40$ & $\$ 40$ \\
\hline $\begin{array}{l}\text { Program costs, USD PPP 2014, calculated as if all incurred immediately at } \\
\text { beginning of year } 0\end{array}$ & $\$ 631$ & $\$ 260$ & $\$ 88$ \\
\hline Program costs, USD PPP 2014, inflated to year 3 at $5 \%$ annual discount rate & $\$ 731$ & $\$ 301$ & $\$ 102$ \\
\hline \multicolumn{4}{|l|}{ BENEFITS PER CAPITA, USD PPP } \\
\hline \multirow{2}{*}{$\begin{array}{l}\text { Year } 1 \text { annual nondurable consumption ITT (assuming treatment effect equal } \\
\text { to year } 2 \text { for asset only) }\end{array}$} & 17 & 10 & -8 \\
\hline & (34) & (31) & (34) \\
\hline \multirow{2}{*}{$\begin{array}{l}\text { Year } 1 \text { annual nondurable consumption ITT (assuming treatment effect equal } \\
\text { to value of asset for asset only) }\end{array}$} & & & 36 \\
\hline & & & \\
\hline \multirow{2}{*}{ Year 2 annual nondurable consumption ITT treatment effect } & $53^{* *}$ & $65^{* *}$ & -8 \\
\hline & $(21)$ & $(22)$ & (34) \\
\hline \multirow{2}{*}{ Year 3 household asset ITT treatment effect } & $17^{* *}$ & -1 & -1 \\
\hline & (5) & (5) & (9) \\
\hline \multirow{2}{*}{ Year 3 nondurable annual consumption ITT treatment effect } & $40^{* *}$ & -5 & -1 \\
\hline & $(16)$ & $(15)$ & $(24)$ \\
\hline $\begin{array}{l}\text { Year } 4 \text { onward total consumption ITT treatment effect, assuming year } 3 \text { gains } \\
\text { persist in perpetuity }\end{array}$ & 760 & -95 & -19 \\
\hline $\begin{array}{l}\text { Total benefits, assuming year } 1 \text { nondurable consumption effect equal to year } 2 \\
\text { for asset only }\end{array}$ & 887 & -26 & -37 \\
\hline $\begin{array}{l}\text { Total benefits, assuming year } 1 \text { nondurable consumption effect equal to value } \\
\text { of asset for asset only }\end{array}$ & & & 7 \\
\hline \multicolumn{4}{|l|}{ BENEFIT/COST RATIOS } \\
\hline $\begin{array}{l}\text { Total benefits/total costs ratio, assuming year } 1 \text { nondurable consumption } \\
\text { effect equal to year } 2 \text { for asset only }\end{array}$ & 1.21 & -0.09 & -0.36 \\
\hline $\begin{array}{l}\text { Total benefits/total costs ratio, assuming year } 1 \text { nondurable consumption } \\
\text { effect equal to value of asset for asset only }\end{array}$ & & & 0.07 \\
\hline
\end{tabular}

Estimates of benefits come from Appendix Tables 14, 15, and 16. Stars report significance of estimates according to the q-values from our Bonferonni procedure, taking into account all the hypotheses in each table. Note that the negative estimates driving benefit/cost ratios to be negative for SOUP and asset only are not statistically different from zero, and in fact, these negative estimates are not robust to a specification that uses per household measures of benefits, as evidenced by column 2 of Appendix Table 16. (This is because asset only households are slightly larger than asset spillover households, and our specification includes village fixed effects.) Since we don't have data from year 1 for asset only, we calculate benefits under two assumptions: (1) that year 1 consumption effects were equal to those of year 2; (2) that year 1 consumption effects were equal to the value of the asset. 
Appendix Figure 1: Distribution of Household Size at Two Years

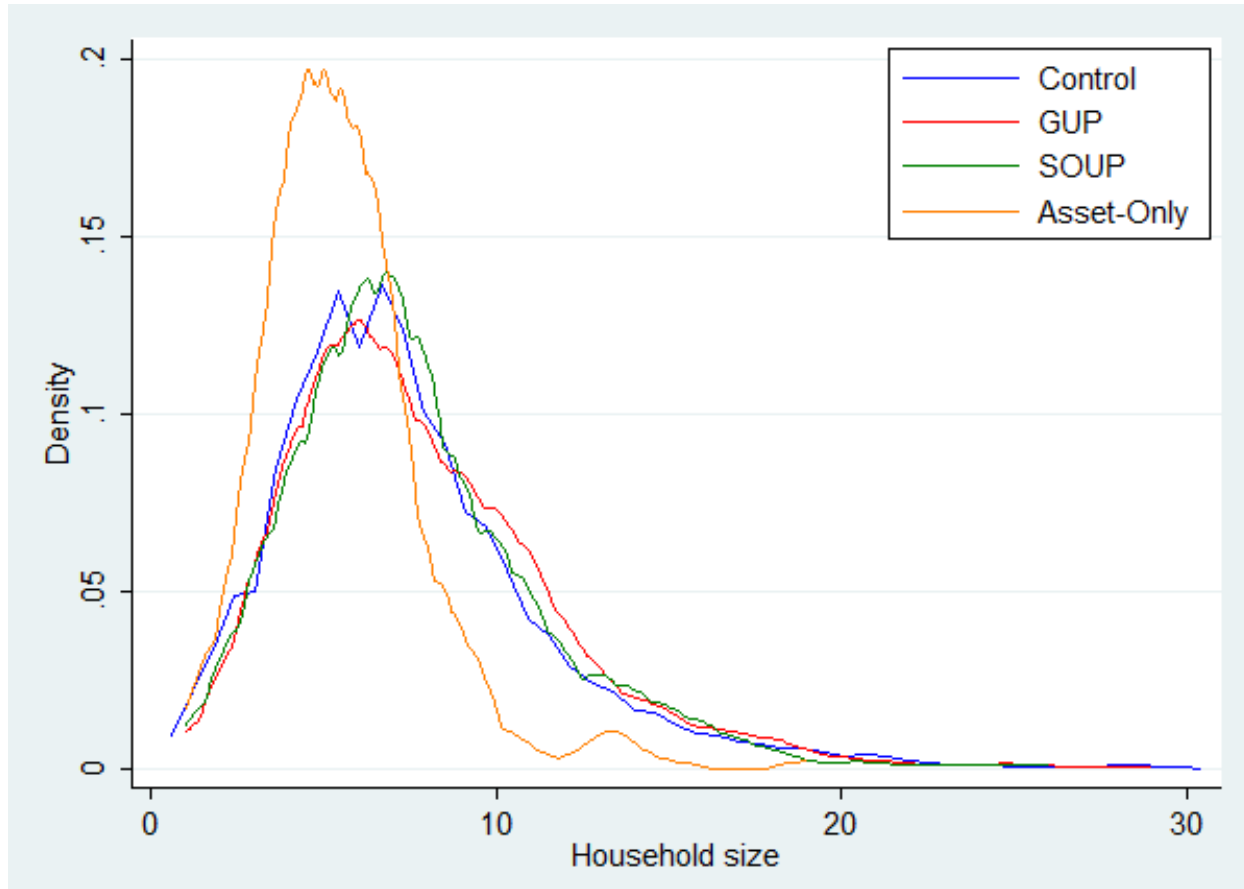

Appendix Table 1: Program Details

\section{Location \\ Implementing NGO}

Type of NGO

Financial instituion partner

Eligibility requirements

Method of identifying participants Savings component

\section{Health component}

Asset transfer

Value of asset transfer

Most common asset chosen

2nd most common asset chosen

3rd most common asset chosen

Consumption support

Freq. household visits
Northern and Upper East regions

Presbyterian Agricultural Services (PAS) and Innovations for Poverty Action (IPA)

Local NGO

Services provided by PAS

Exclusion criteria included: (i) ownership of $>30$ small ruminants or $>50$ fowl; (ii) member found to be alcoholic or drug addict; (iii) no strong, able-bodied adult; (iv) did not have a female member; (v) did not have a member between ages of 18 and 65 Participatory Wealth Ranking at Village Level

Half of GUP households received savings accounts (savings collected during weekly visits by field agents, households receive passbooks to log deposits)

Health and nutrition education. Beneficiaries were enrolled in the National Health Insurance Scheme.

July 2011-July 2012

GHS 300 (PPP USD 451.38)

Goats and hens (44\%)

Goats and maize inputs $(27 \%)$

Shea nuts and hens $(6 \%)$

Treatment households received weekly cash transfers of GHS 4 to 6 (PPP USD 6.02 to 9.03) (amount dependent on household size) during lean season

Weekly over 24 months 
Appendix Table 2: Experiment Design

\begin{tabular}{|c|c|c|}
\hline & Households & Villages \\
\hline control villages & 1299 & 76 \\
\hline GUP control & 642 & \\
\hline GUP without savings & 333 & 78 \\
\hline GUP with savings & 333 & \\
\hline SOUP control & 510 & \\
\hline SOUP without match & 371 & 77 \\
\hline SOUP with match & 362 & \\
\hline $\begin{array}{l}\text { asset only control } \\
\text { asset only }\end{array}$ & $\begin{array}{l}163 \\
164\end{array}$ & 45 \\
\hline TOTAL & 4177 & 276 \\
\hline \multicolumn{3}{|c|}{$\begin{array}{l}\text { In control villages, none of the households received any treatment. In GUP (Graduation } \\
\text { from Ultra Poverty) villages, GUP control households received no treatment, GUP without } \\
\text { savings households received the full GUP program, and GUP with savings households } \\
\text { received the full GUP program plus the opportunity to deposit savings during weekly } \\
\text { visits. In SOUP (Savings out of Ultra Poverty) villages, SOUP control households received } \\
\text { no treatment, SOUP without match households received the opportunity to deposit savings } \\
\text { during weekly visits, and SOUP with match households received SOUP with a } 50 \% \text { match. } \\
\text { In asset only villages, asset only control households received no treatment, and asset only } \\
\text { households received goats. }\end{array}$} \\
\hline
\end{tabular}

Appendix Table 3: Program Components by Treatment

\begin{tabular}{|c|c|c|c|c|c|c|c|c|c|}
\hline & $\begin{array}{l}\text { GUP } \\
\text { with } \\
\text { savings }\end{array}$ & $\begin{array}{l}\text { GUP } \\
\text { without } \\
\text { savings }\end{array}$ & $\begin{array}{l}\text { GUP } \\
\text { Control }\end{array}$ & $\begin{array}{l}\text { SOUP } \\
\text { with } \\
\text { match }\end{array}$ & $\begin{array}{l}\text { SOUP } \\
\text { without } \\
\text { match }\end{array}$ & $\begin{array}{l}\text { SOUP } \\
\text { Control }\end{array}$ & $\begin{array}{l}\text { Asset } \\
\text { Only }\end{array}$ & $\begin{array}{l}\text { Asset } \\
\text { Only } \\
\text { Control }\end{array}$ & $\begin{array}{l}\text { Pure } \\
\text { Control }\end{array}$ \\
\hline $\begin{array}{l}\text { Transfer of asset, chosen by } \\
\text { household (w/ goats as op- } \\
\text { tion) }\end{array}$ & $\mathrm{x}$ & $\mathrm{x}$ & & & & & & & \\
\hline Transfer of four goats & & & & & & & $\mathrm{x}$ & & \\
\hline $\begin{array}{l}\text { Consumption support, } \\
\text { training, coaching, etc. }\end{array}$ & $\mathrm{x}$ & $\mathrm{x}$ & & & & & & & \\
\hline $\begin{array}{l}\text { Access to savings deposit } \\
\text { collector }\end{array}$ & $\mathrm{x}$ & & & $\mathrm{x}$ & $\mathrm{x}$ & & & & \\
\hline $\begin{array}{l}\text { Savings deposits matched } \\
\text { at } 50 \%\end{array}$ & & & & $\mathrm{x}$ & & & & & \\
\hline $\begin{array}{l}\text { No services provided to } \\
\text { household }\end{array}$ & & & $\mathrm{x}$ & & & $\mathrm{x}$ & & $\mathrm{x}$ & $\mathrm{x}$ \\
\hline $\begin{array}{l}\text { Others in village received } \\
\text { "GUP" }\end{array}$ & & & $\mathrm{x}$ & & & & & & \\
\hline $\begin{array}{l}\text { Others in village received } \\
\text { "SOUP" }\end{array}$ & & & & & & $\mathrm{x}$ & & & \\
\hline $\begin{array}{l}\text { Others in village received } \\
\text { four goats }\end{array}$ & & & & & & & & $\mathrm{x}$ & \\
\hline
\end{tabular}


Appendix Table 4: Attrition

\begin{tabular}{l|cc}
\hline & Two-Year & Three-Year \\
\hline Completed Surveys & 4121 & 4103 \\
Response Rate & 0.99 & 0.98 \\
p-value from F-test of Joint Sig of Treatments & 0.10 & 0.22 \\
\hline
\end{tabular}

We report response rates from our total sample of 4,177 households for the two-year and three-year measures. Since our two-year measure takes the average of outcomes over four surveys (two midlines, endline, and agricultural endline), we define attrition to be 1 only if the household was not found for all four surveys. Likewise, since our three-year measure takes the average of outcomes over two surveys (follow-up, agricultural follow-up), we define attrition to be 1 only if the household was not found for both surveys. In the final row we report the p-value from an F-test of joint significance of the coefficients from an OLS regression of attrition on GUP-no-savings, GUP-savings, SOUP-no-match, SOUP-match, and asset. 
Appendix Table 5: Descriptive Statistics for Baseline Indicators, Excluding Asset Only and Asset Only Control Means (Standard Deviations)

\begin{tabular}{|c|c|c|c|c|c|c|}
\hline & ctrl HHs & $\begin{array}{c}\text { GUP } \\
\text { savings }\end{array}$ & $\begin{array}{l}\text { GUP no } \\
\text { savings }\end{array}$ & $\begin{array}{l}\text { SOUP no } \\
\text { match }\end{array}$ & $\begin{array}{l}\text { SOUP } \\
\text { match }\end{array}$ & $\begin{array}{c}\text { p-value, } \\
\text { F-test joint } \\
\text { sig }\end{array}$ \\
\hline household size & $\begin{array}{c}7.17 \\
(3.84)\end{array}$ & $\begin{array}{c}7.27 \\
(3.86)\end{array}$ & $\begin{array}{c}7.54 \\
(3.82)\end{array}$ & $\begin{array}{c}7.11 \\
(3.28)\end{array}$ & $\begin{array}{c}7.37 \\
(3.81)\end{array}$ & 0.52 \\
\hline average age, household & $\begin{array}{c}25.17 \\
(10.60)\end{array}$ & $\begin{array}{l}24.40 \\
(9.49)\end{array}$ & $\begin{array}{c}24.91 \\
(10.47)\end{array}$ & $\begin{array}{l}23.47 \\
(9.86)\end{array}$ & $\begin{array}{l}24.59 \\
(9.72)\end{array}$ & 0.09 \\
\hline land area (acres) & $\begin{array}{c}4.68 \\
(4.63)\end{array}$ & $\begin{array}{c}4.97 \\
(4.44)\end{array}$ & $\begin{array}{c}4.65 \\
(3.98)\end{array}$ & $\begin{array}{c}4.67 \\
(4.04)\end{array}$ & $\begin{array}{c}4.96 \\
(4.84)\end{array}$ & 0.74 \\
\hline monthly per cap cons. (USD) & $\begin{array}{c}57.05 \\
(38.07)\end{array}$ & $\begin{array}{c}56.49 \\
(39.36)\end{array}$ & $\begin{array}{c}54.59 \\
(34.43)\end{array}$ & $\begin{array}{c}57.20 \\
(37.98)\end{array}$ & $\begin{array}{c}58.54 \\
(39.33)\end{array}$ & 0.70 \\
\hline monthly HH income (USD) & $\begin{array}{c}41.56 \\
(54.92)\end{array}$ & $\begin{array}{c}45.98 \\
(55.96)\end{array}$ & $\begin{array}{c}40.39 \\
(50.83)\end{array}$ & $\begin{array}{c}41.44 \\
(50.72)\end{array}$ & $\begin{array}{c}47.15 \\
(55.58)\end{array}$ & 0.32 \\
\hline savings balances (USD) & $\begin{array}{c}2.34 \\
(11.99)\end{array}$ & $\begin{array}{c}3.79 \\
(14.42)\end{array}$ & $\begin{array}{c}1.04 \\
(6.77)\end{array}$ & $\begin{array}{c}3.40 \\
(16.02)\end{array}$ & $\begin{array}{c}2.48 \\
(11.82)\end{array}$ & 0.00 \\
\hline food security index & $\begin{array}{l}-0.04 \\
(0.98)\end{array}$ & $\begin{array}{c}0.05 \\
(1.02)\end{array}$ & $\begin{array}{c}0.00 \\
(1.02)\end{array}$ & $\begin{array}{c}0.11 \\
(1.04)\end{array}$ & $\begin{array}{c}0.10 \\
(1.06)\end{array}$ & 0.06 \\
\hline asset value index & $\begin{array}{c}0.01 \\
(1.06)\end{array}$ & $\begin{array}{c}0.00 \\
(0.90)\end{array}$ & $\begin{array}{l}-0.01 \\
(0.84)\end{array}$ & $\begin{array}{l}-0.02 \\
(0.88)\end{array}$ & $\begin{array}{l}-0.04 \\
(0.90)\end{array}$ & 0.93 \\
\hline financial inclusion index & $\begin{array}{l}-0.02 \\
(0.96)\end{array}$ & $\begin{array}{c}0.07 \\
(1.07)\end{array}$ & $\begin{array}{l}-0.11 \\
(0.69)\end{array}$ & $\begin{array}{c}0.13 \\
(1.27)\end{array}$ & $\begin{array}{c}0.06 \\
(1.11)\end{array}$ & 0.00 \\
\hline physical health index & $\begin{array}{l}-0.01 \\
(1.01)\end{array}$ & $\begin{array}{c}0.04 \\
(0.97)\end{array}$ & $\begin{array}{c}0.03 \\
(0.98)\end{array}$ & $\begin{array}{l}-0.02 \\
(1.02)\end{array}$ & $\begin{array}{c}0.06 \\
(0.95)\end{array}$ & 0.12 \\
\hline mental health index & $\begin{array}{l}-0.02 \\
(1.01)\end{array}$ & $\begin{array}{c}0.00 \\
(0.98)\end{array}$ & $\begin{array}{l}-0.04 \\
(0.93)\end{array}$ & $\begin{array}{c}0.12 \\
(1.03)\end{array}$ & $\begin{array}{c}0.05 \\
(0.97)\end{array}$ & 0.16 \\
\hline political involvement index & $\begin{array}{c}0.01 \\
(1.00)\end{array}$ & $\begin{array}{c}0.04 \\
(1.00)\end{array}$ & $\begin{array}{c}0.00 \\
(1.00)\end{array}$ & $\begin{array}{l}-0.13 \\
(1.01)\end{array}$ & $\begin{array}{c}0.01 \\
(1.00)\end{array}$ & 0.15 \\
\hline female empowerment index & $\begin{array}{c}0.00 \\
(0.99)\end{array}$ & $\begin{array}{c}0.05 \\
(1.03)\end{array}$ & $\begin{array}{c}0.01 \\
(1.03)\end{array}$ & $\begin{array}{l}-0.02 \\
(1.01)\end{array}$ & $\begin{array}{l}-0.05 \\
(0.98)\end{array}$ & 0.76 \\
\hline
\end{tabular}

We report means and standard deviations for key indicators at baseline. Indices are centered around mean baseline value. The last column contains the p-value from an F-test of joint significance of all treatments. In the results section, we report p-values from each specification using baseline outcomes to check balance on the key pairwise comparisons. We exclude Asset Only and Asset Only Control households because we do not have baseline data for them. See Appendix for components of all indices. 
Appendix Table 6: Do Two-Year Variables Used as Controls Change with GUP and SOUP?

\begin{tabular}{cl|ccc}
\hline & & $(1)$ & $(2)$ & $(3)$ \\
& & average age in HH & HH size & HH has metal roof \\
\hline \multirow{2}{*}{ SOUP } & itt & 0.250 & 0.010 & 0.018 \\
& se & $(0.350)$ & $(0.099)$ & $(0.025)$ \\
GUP & p-val & 0.476 & 0.916 & 0.478 \\
& itt & 0.000 & 0.205 & -0.027 \\
& se & $(0.317)$ & $(0.115)$ & $(0.028)$ \\
& p-val & 1.000 & $0.074^{*}$ & 0.345 \\
\hline & ctrl mean & 23.6 & 7.4 & 0.3 \\
& ctrl sd & 10.2 & 3.9 & 0.5 \\
& obs & 3850 & 3850 & 3850 \\
\hline \hline \multirow{2}{*}{ asset } & itt & 0.090 & 0.264 & 0.030 \\
& se & $(1.557)$ & $(0.319)$ & $0.051)$ \\
& p-val & 0.954 & 0.408 & 0.555 \\
\hline & ctrl mean & 23.7 & 7.3 & 0.3 \\
& ctrl sd & 10.7 & 3.9 & 0.5 \\
& obs & 4177 & 4177 & 4177 \\
\hline
\end{tabular}

Estimates from OLS regressions of two-year variables to be used as controls for analysis of asset drop, which has no baseline data, on pooled treatments. The omitted group is control households in all villages. We control for re-randomization variables, the baseline value of the outcome, and employment program treatments. We include fixed effects for all villages except those assigned to pure control. Standard errors clustered at unit of randomization (village for pure control, individual otherwise). 
Appendix Table 7: Effects of Savings Treatments on Savings Stocks

\begin{tabular}{lccccc}
\hline & $\begin{array}{c}(1) \\
\text { cum. deposits } \\
\text { VARD) }\end{array}$ & $\begin{array}{c}(2) \\
\text { withdrawals } \\
\text { (USD) }\end{array}$ & $\begin{array}{c}(3) \\
\text { balances } \\
\text { (USD) }\end{array}$ & $\begin{array}{c}(4) \\
\text { self-reported balances } \\
\text { two-year (USD) }\end{array}$ & $\begin{array}{c}(5) \\
\text { self-reported balances } \\
\text { three-year (USD) }\end{array}$ \\
\hline SOUP no match & & & & $11.92^{* * *}$ & $(2.28)$ \\
SOUP match & 7.70 & $12.53^{* * *}$ & -4.84 & $13.96^{* * *}$ & $\left(1.59^{* * *}\right.$ \\
& $(5.89)$ & $(3.78)$ & $(4.93)$ & $(2.70)$ & $3.01^{* *}$ \\
GUP no savings & & & & $4.10^{*}$ & $(1.38)$ \\
GUP savings & $114.93^{* * *}$ & $54.40^{* * *}$ & $60.49^{* * *}$ & $28.15)$ & $4.71^{* * *}$ \\
& $(9.33)$ & $(5.63)$ & $(7.14)$ & $(3.41)$ & $(1.67)$ \\
& & & & & $9.57^{* * *}$ \\
Observations & 1,064 & 1,063 & 1,063 & 3.703 & $(2.15)$ \\
Control mean & 92.7 & 24.4 & 68.4 & 5.49 & 3,597 \\
\hline
\end{tabular}

Columns 1-3 use administrative data (from savings collectors) on cumulative deposits, withdrawals, and total balances for treatment groups that participated in a savings component. The omitted group is SOUP no match. We include station fixed effects and report heteroskedasticity robust standard errors. Column 4 uses two-year survey data on total savings balances. The omitted group is control households in all villages. We include include interviewer fixed effects and fixed effects for whether or not the household was surveyed in each midline. We cluster standard errors at the unit of randomization (village for pure control, individual otherwise). In all columns, we control for employment program treatment assignment.

Appendix Table 8: Two-Year Differences between GUP with/without Savings, SOUP with/without Match

\begin{tabular}{|c|c|c|c|c|c|c|}
\hline & & $\begin{array}{c}(1) \\
\text { asset value } \\
\text { index }\end{array}$ & $\begin{array}{c}(2) \\
\text { consumption } \\
\text { index }\end{array}$ & $\begin{array}{c}(3) \\
\text { financial } \\
\text { inclusion index }\end{array}$ & $\begin{array}{l}\text { food security } \\
\text { index }\end{array}$ & $\begin{array}{c}(5) \\
\text { income index }\end{array}$ \\
\hline \multirow[t]{4}{*}{ SOUP match - SOUP no match } & diff & -0.046 & 0.020 & 0.073 & 0.069 & 0.033 \\
\hline & se & $(0.076)$ & $(0.052)$ & $(0.145)$ & $(0.049)$ & $(0.056)$ \\
\hline & p-val & 0.550 & 0.705 & 0.615 & 0.162 & 0.563 \\
\hline & bsl p-val & 0.291 & 0.906 & 0.141 & 0.452 & 0.350 \\
\hline \multirow{5}{*}{ GUP sav. - GUP no sav. } & diff & -0.117 & -0.057 & 1.074 & -0.121 & 0.068 \\
\hline & & $(0.070)$ & $(0.050)$ & $(0.149)$ & $(0.050)$ & $(0.058)$ \\
\hline & p-val & $0.095^{*}$ & 0.257 & $0.000^{* * *}$ & $0.015^{* *}$ & 0.242 \\
\hline & bsl p-val & 0.829 & 0.572 & $0.050^{* *(+)}$ & 0.492 & 0.296 \\
\hline & obs & 3801 & 3707 & 3708 & 3708 & 3800 \\
\hline
\end{tabular}

Differences between GUP and SOUP sub-treatments, for household-level economic indices from year two (averaging over two-year outcome and midline outcomes that were collected at least one year after treatment start). OLS regressions include controls for re-randomization variables and the baseline value of the outcome. We include controls for employment program treatments. We also include interviewer fixed effects and fixed effects for whether or not the household was surveyed in each midline. Standard errors clustered at unit of randomization (village for pure control, individual otherwise). Finally, we report p-values for the same specification using the baseline value of each outcome. We use a superscript $(+)$ to indicate a positive t-statistic. Indices are centered around baseline values. See appendix for detailed descriptions of each variable. 
Appendix Table 9: Three-Year Differences between GUP with/without Savings, SOUP with/without Match

\begin{tabular}{|c|c|c|c|c|c|c|}
\hline & & $\begin{array}{l}(1) \\
\text { asset value } \\
\text { index }\end{array}$ & $\begin{array}{c}(2) \\
\text { consumption } \\
\text { index }\end{array}$ & $\begin{array}{c}(3) \\
\text { financial } \\
\text { inclusion index }\end{array}$ & $\begin{array}{c}(4) \\
\text { food security } \\
\text { index }\end{array}$ & $\begin{array}{c}(5) \\
\text { income index }\end{array}$ \\
\hline \multirow[t]{4}{*}{ SOUP match - SOUP no match } & diff & 0.012 & 0.061 & -0.079 & -0.012 & 0.055 \\
\hline & se & $(0.096)$ & $(0.040)$ & $(0.090)$ & $(0.051)$ & $(0.072)$ \\
\hline & p-val & 0.897 & 0.125 & 0.384 & 0.808 & 0.443 \\
\hline & bsl p-val & 0.291 & 0.906 & 0.141 & 0.452 & 0.350 \\
\hline \multirow[t]{5}{*}{ GUP sav. - GUP no sav. } & diff & 0.038 & -0.074 & 0.328 & -0.021 & 0.041 \\
\hline & se & $(0.083)$ & $(0.041)$ & $(0.115)$ & $(0.049)$ & $(0.080)$ \\
\hline & p-val & 0.643 & $0.071^{*}$ & $0.005^{* * *}$ & 0.671 & 0.605 \\
\hline & bsl p-val & 0.829 & 0.572 & $0.050^{* *(+)}$ & 0.492 & 0.296 \\
\hline & obs & 3781 & 3597 & 3603 & 3603 & 3781 \\
\hline
\end{tabular}

Differences between GUP and SOUP sub-treatments, for household-level economic indices from year two (averaging over two-year outcome and midline outcomes that were collected at least one year after treatment start). OLS regressions include controls for re-randomization variables and the baseline value of the outcome. We include controls for employment program treatments. We also include interviewer fixed effects and fixed effects for whether or not the household was surveyed in each midline. Standard errors clustered at unit of randomization (village for pure control, individual otherwise). Finally, we report p-values for the same specification using the baseline value of each outcome. We use a superscript $(+)$ to indicate a positive t-statistic. Indices are centered around baseline values. See appendix for detailed descriptions of each variable. 
Appendix Table 10: Two-Year Effects of GUP, SOUP, and Asset Only on Household-Level Non-Economic Indices

\begin{tabular}{|c|c|c|c|c|c|c|}
\hline & & $\begin{array}{l}\text { (1) } \\
\text { physical health } \\
\text { index }\end{array}$ & $\begin{array}{c}(2) \\
\text { mental health } \\
\text { index }\end{array}$ & $\begin{array}{c}(3) \\
\text { political } \\
\text { involvement } \\
\text { index }\end{array}$ & $\begin{array}{c}(4) \\
\text { time at work } \\
\text { index }\end{array}$ & $\begin{array}{c}(5) \\
\text { female } \\
\text { empowerment } \\
\text { index }\end{array}$ \\
\hline \multicolumn{7}{|c|}{ PANEL A: GUP vs. SOUP } \\
\hline \multirow[t]{5}{*}{ SOUP } & itt & -0.046 & 0.068 & -0.028 & -0.002 & -0.075 \\
\hline & se & $(0.034)$ & $(0.060)$ & $(0.062)$ & $(0.058)$ & $(0.035)$ \\
\hline & p-val & 0.182 & 0.257 & 0.654 & 0.974 & $0.032^{* *}$ \\
\hline & q-val & 0.456 & 0.540 & 0.819 & 0.986 & 0.129 \\
\hline & bsl p-val & 0.125 & 0.267 & 0.294 & . & 0.272 \\
\hline \multirow[t]{5}{*}{ GUP no sav. } & itt & 0.011 & 0.178 & 0.123 & 0.055 & 0.022 \\
\hline & se & $(0.040)$ & $(0.071)$ & $(0.069)$ & $(0.081)$ & $(0.043)$ \\
\hline & p-val & 0.775 & $0.012^{* *}$ & $0.075^{*}$ & 0.495 & 0.613 \\
\hline & q-val & 0.862 & 0.106 & 0.250 & 0.774 & 0.819 \\
\hline & bsl p-val & 0.124 & 0.966 & 0.914 & . & $0.049^{* *(+)}$ \\
\hline \multirow[t]{5}{*}{ GUP sav. } & & 0.059 & 0.077 & 0.249 & -0.001 & 0.028 \\
\hline & & $(0.041)$ & $(0.069)$ & $(0.067)$ & $(0.077)$ & $(0.042)$ \\
\hline & p-val & 0.146 & 0.270 & $0.000^{* * *}$ & 0.986 & 0.503 \\
\hline & q-val & 0.418 & 0.540 & $0.004^{* * *}$ & 0.986 & 0.774 \\
\hline & bsl p-val & 0.283 & 0.644 & 0.752 & . & $0.022^{* *(+)}$ \\
\hline \multirow{4}{*}{ GUP sav. - SOUP } & diff & 0.105 & 0.009 & 0.277 & 0.001 & 0.103 \\
\hline & se & $(0.049)$ & $(0.087)$ & $(0.086)$ & $(0.094)$ & $(0.052)$ \\
\hline & p-val & $0.033^{* *}$ & 0.916 & $0.001^{* * *}$ & 0.996 & $0.047^{* *}$ \\
\hline & bsl p-val & 0.835 & 0.681 & 0.326 & . & $0.010^{* * *(+)}$ \\
\hline \multirow{5}{*}{ any GUP } & & 0.035 & 0.127 & 0.187 & 0.026 & 0.025 \\
\hline & & $(0.035)$ & $(0.060)$ & $(0.059)$ & $(0.069)$ & $(0.036)$ \\
\hline & p-val & 0.316 & $0.034^{* *}$ & $0.002^{* * *}$ & 0.700 & 0.490 \\
\hline & bsl p-val & 0.135 & 0.806 & 0.904 & . & $0.012^{* *(+)}$ \\
\hline & obs & 26664 & 3479 & 3486 & 3484 & 3471 \\
\hline \multicolumn{7}{|c|}{ PANEL B: GUP vs. Asset Only } \\
\hline \multirow[t]{7}{*}{ asset } & itt & 0.020 & -0.259 & -0.053 & 0.329 & -0.052 \\
\hline & se & $(0.062)$ & $(0.114)$ & $(0.111)$ & $(0.136)$ & $(0.070)$ \\
\hline & p-val & 0.752 & $0.023^{* *}$ & 0.634 & $0.016^{* *}$ & 0.458 \\
\hline & q-val & 0.862 & 0.117 & 0.819 & 0.106 & 0.774 \\
\hline & itt, ctrls & 0.023 & -0.262 & -0.051 & 0.322 & -0.055 \\
\hline & p-val, ctrls & 0.708 & $0.021^{* *}$ & 0.644 & $0.018^{* *}$ & 0.437 \\
\hline & q-val, ctrls & 0.709 & $0.054^{*}$ & 0.709 & $0.054^{*}$ & 0.709 \\
\hline \multirow[t]{6}{*}{ GUP no sav. - asset } & diff & -0.004 & 0.437 & 0.171 & -0.273 & 0.076 \\
\hline & se & $(0.074)$ & $(0.135)$ & $(0.131)$ & $(0.159)$ & $(0.083)$ \\
\hline & p-val & 0.959 & $0.001^{* * *}$ & 0.192 & $0.085^{*}$ & 0.360 \\
\hline & itt, ctrls & -0.012 & 0.432 & 0.158 & -0.266 & 0.080 \\
\hline & p-val, ctrls & 0.875 & $0.001^{* * *}$ & 0.228 & $0.093^{*}$ & 0.337 \\
\hline & obs & 28399 & 3749 & 3757 & 3753 & 3738 \\
\hline
\end{tabular}

Estimates from OLS regressions of household-member-level non-economic indices at year two (averaging over two-year outcome and midline outcomes that were collected at least one year after treatment start) on treatments. The omitted group is control households in all villages. The regression in Panel A excludes the asset only villages and includes controls for re-randomization variables and the baseline value of the outcome. The regression in Panel B includes the asset only villages (without baseline controls). Both panels include controls for employment program treatments. We include fixed effects for all villages except those assigned to pure control, and dummies for whether or not the household was surveyed in each midline. Standard errors clustered at unit of randomization (village for pure control, individual otherwise). We use the Benjamini-Hochberg step-up method to compute q-values, considering the 20 independent hypotheses in the table. For regressions that include asset households, we also report p-values and q-values for a specification with three two-year variables as controls, since we have no baseline controls. (See appendix for evidence that these variables were mostly not affected by the GUP or SOUP treatments.) Finally, we report p-values for the same specification using the baseline value of each outcome. We use a superscript $(+)$ to indicate a positive t-statistic. Indices are centered around baseline values. See appendix for detailed descriptions of each variable. 
Appendix Table 11: Three-Year Effects of GUP, SOUP, and Asset Only on Household-Level Non-Economic Indices

\begin{tabular}{|c|c|c|c|c|c|c|}
\hline & & $\begin{array}{l}\text { (1) } \\
\text { physical health } \\
\text { index }\end{array}$ & $\begin{array}{l}(2) \\
\text { mental health } \\
\text { index }\end{array}$ & $\begin{array}{c}(3) \\
\text { political } \\
\text { involvement } \\
\text { index }\end{array}$ & $\begin{array}{c}(4) \\
\text { time at work } \\
\text { index }\end{array}$ & $\begin{array}{c}(5) \\
\text { female } \\
\text { empowerment } \\
\text { index }\end{array}$ \\
\hline \multicolumn{7}{|c|}{ PANEL A: GUP vs. SOUP } \\
\hline \multirow[t]{5}{*}{ SOUP } & itt & -0.048 & 0.014 & 0.048 & -0.033 & -0.077 \\
\hline & se & $(0.033)$ & $(0.055)$ & $(0.066)$ & $(0.061)$ & $(0.036)$ \\
\hline & p-val & 0.142 & 0.804 & 0.471 & 0.580 & $0.034^{* *}$ \\
\hline & q-val & 0.711 & 0.850 & 0.850 & 0.850 & 0.396 \\
\hline & bsl p-val & 0.125 & 0.267 & 0.294 & & 0.272 \\
\hline \multirow[t]{5}{*}{ GUP no sav. } & & 0.019 & -0.040 & 0.057 & 0.056 & -0.031 \\
\hline & se & $(0.036)$ & $(0.065)$ & $(0.077)$ & $(0.066)$ & $(0.043)$ \\
\hline & p-val & 0.604 & 0.543 & 0.463 & 0.397 & 0.470 \\
\hline & q-val & 0.850 & 0.850 & 0.850 & 0.850 & 0.850 \\
\hline & bsl p-val & 0.124 & 0.966 & 0.914 & 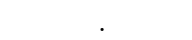 & $0.049^{* *(+)}$ \\
\hline \multirow[t]{5}{*}{ GUP sav. } & & -0.011 & 0.014 & 0.122 & 0.045 & 0.045 \\
\hline & & $(0.038)$ & $(0.065)$ & $(0.076)$ & $(0.066)$ & $(0.042)$ \\
\hline & p-val & 0.769 & 0.830 & 0.111 & 0.491 & 0.281 \\
\hline & q-val & 0.850 & 0.850 & 0.711 & 0.850 & 0.850 \\
\hline & bsl p-val & 0.283 & 0.644 & 0.752 & 年 & $0.022^{* *(+)}$ \\
\hline \multirow[t]{4}{*}{ GUP sav. - SOUP } & diff & 0.037 & 0.000 & 0.074 & 0.079 & 0.122 \\
\hline & & $(0.046)$ & $(0.081)$ & $(0.094)$ & $(0.085)$ & $(0.053)$ \\
\hline & p-val & 0.420 & 0.997 & 0.431 & 0.354 & $0.020^{* *}$ \\
\hline & bsl p-val & 0.835 & 0.681 & 0.326 & - & $0.010^{* * *(+)}$ \\
\hline \multirow[t]{5}{*}{ any GUP } & & 0.004 & -0.013 & 0.089 & 0.051 & 0.007 \\
\hline & & $(0.033)$ & $(0.055)$ & $(0.066)$ & $(0.055)$ & $(0.037)$ \\
\hline & p-val & 0.893 & 0.810 & 0.179 & 0.357 & 0.858 \\
\hline & bsl p-val & 0.135 & 0.806 & 0.904 & . & $0.012^{* *(+)}$ \\
\hline & obs & 25940 & 3396 & 3404 & 3389 & 3396 \\
\hline \multicolumn{7}{|c|}{ PANEL B: GUP vs. Asset Only } \\
\hline \multirow[t]{7}{*}{ asset } & itt & -0.056 & 0.205 & 0.021 & -0.031 & 0.028 \\
\hline & se & $(0.064)$ & $(0.099)$ & $(0.112)$ & $(0.120)$ & $(0.060)$ \\
\hline & p-val & 0.378 & $0.040^{* *}$ & 0.850 & 0.794 & 0.641 \\
\hline & q-val & 0.850 & 0.396 & 0.850 & 0.850 & 0.850 \\
\hline & itt, ctrls & -0.057 & 0.201 & 0.015 & -0.035 & 0.028 \\
\hline & p-val, ctrls & 0.372 & $0.043^{* *}$ & 0.893 & 0.769 & 0.645 \\
\hline & q-val, ctrls & 0.893 & 0.217 & 0.893 & 0.893 & 0.893 \\
\hline \multirow[t]{6}{*}{ GUP no sav. - asset } & diff & 0.076 & -0.247 & 0.024 & 0.078 & -0.060 \\
\hline & se & $(0.074)$ & $(0.119)$ & $(0.136)$ & $(0.138)$ & $(0.074)$ \\
\hline & p-val & 0.301 & $0.038^{* *}$ & 0.861 & 0.572 & 0.419 \\
\hline & itt, ctrls & 0.070 & -0.255 & 0.022 & 0.085 & -0.049 \\
\hline & p-val, ctrls & 0.341 & $0.032^{* *}$ & 0.873 & 0.536 & 0.511 \\
\hline & obs & 27515 & 3674 & 3683 & 3665 & 3675 \\
\hline
\end{tabular}

Estimates from OLS regressions of household-member-level non-economic indices at year two (averaging over two-year outcome and midline outcomes that were collected at least one year after treatment start) on treatments. The omitted group is control households in all villages. The regression in Panel A excludes the asset only villages and includes controls for re-randomization variables and the baseline value of the outcome. The regression in Panel B includes the asset only villages (without baseline controls). Both panels include controls for employment program treatments. We include fixed effects for all villages except those assigned to pure control, and dummies for whether or not the household was surveyed in each midline. Standard errors clustered at unit of randomization (village for pure control, individual otherwise). We use the Benjamini-Hochberg step-up method to compute q-values, considering the 20 independent hypotheses in the table. For regressions that include asset households, we also report p-values and q-values for a specification with three two-year variables as controls, since we have no baseline controls. (See appendix for evidence that these variables were mostly not affected by the GUP or SOUP treatments.) Finally, we report p-values for the same specification using the baseline value of each outcome. We use a superscript $(+)$ to indicate a positive t-statistic. Indices are centered around baseline values. See appendix for detailed descriptions of each variable. 
Appendix Table 12: Two-Year Effects of GUP, SOUP, and Asset Only on Income Sources

\begin{tabular}{|c|c|c|c|c|c|c|}
\hline & & $\begin{array}{c}(1) \\
\text { household has } \\
\text { business }\end{array}$ & $\begin{array}{c}(2) \\
\text { business } \\
\text { income, } \\
\text { monthly (USD) }\end{array}$ & $\begin{array}{c}(3) \\
\text { crop income, } \\
\text { monthly (USD) }\end{array}$ & $\begin{array}{c}(4) \\
\text { animal } \\
\text { revenue, } \\
\text { monthly (USD) }\end{array}$ & $\begin{array}{c}(5) \\
\text { wage income, } \\
\text { monthly (USD) }\end{array}$ \\
\hline \multicolumn{7}{|c|}{ PANEL A: GUP vs. SOUP } \\
\hline \multirow[t]{5}{*}{ SOUP } & itt & 0.036 & 0.055 & 3.531 & -0.650 & 0.106 \\
\hline & se & $(0.026)$ & $(1.244)$ & $(1.986)$ & $(1.077)$ & $(0.539)$ \\
\hline & p-val & 0.175 & 0.965 & $0.076^{*}$ & 0.546 & 0.844 \\
\hline & q-val & 0.350 & 0.965 & 0.189 & 0.729 & 0.954 \\
\hline & bsl p-val & 0.115 & 0.192 & 0.751 & 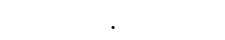 & 0.544 \\
\hline \multirow[t]{5}{*}{ GUP no sav. } & & 0.088 & 3.595 & 2.760 & 0.607 & 0.620 \\
\hline & & $(0.032)$ & $(1.463)$ & $(2.201)$ & $(1.154)$ & $(0.505)$ \\
\hline & p-val & $0.007^{* * *}$ & $0.014^{* *}$ & 0.210 & 0.599 & 0.220 \\
\hline & q-val & $0.060^{*}$ & $0.062^{*}$ & 0.368 & 0.749 & 0.368 \\
\hline & bsl p-val & $0.072^{*(+)}$ & $0.054^{*}$ & 0.879 & 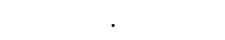 & $0.021^{* *}$ \\
\hline \multirow[t]{5}{*}{ GUP sav. } & & 0.082 & 3.692 & 4.472 & 2.403 & 0.514 \\
\hline & & (0.031) & $(1.522)$ & $(2.390)$ & $(1.155)$ & $(0.510)$ \\
\hline & p-val & $0.009^{* * *}$ & $0.015^{* *}$ & $0.061^{*}$ & $0.038^{* *}$ & 0.314 \\
\hline & q-val & $0.060^{*}$ & $0.062^{*}$ & 0.176 & 0.126 & 0.449 \\
\hline & bsl p-val & $0.022^{* *(+)}$ & 0.853 & 0.894 & . & 0.189 \\
\hline \multirow[t]{4}{*}{ GUP sav. - SOUP } & itt & 0.046 & 3.637 & 0.941 & 3.053 & 0.408 \\
\hline & & $(0.038)$ & $(1.897)$ & $(2.858)$ & (1.471) & $(0.686)$ \\
\hline & p-val & 0.229 & $0.055^{*}$ & 0.742 & $0.038^{* *}$ & 0.552 \\
\hline & bsl p-val & $0.004^{* * *(+)}$ & 0.550 & 0.739 & . & 0.125 \\
\hline \multirow[t]{7}{*}{ any GUP } & & 0.085 & 3.644 & 3.627 & 1.516 & 0.566 \\
\hline & & $(0.027)$ & $(1.257)$ & (1.958) & (0.991) & $(0.427)$ \\
\hline & p-val & $0.002^{* * *}$ & $0.004^{* * *}$ & $0.064^{*}$ & 0.126 & 0.185 \\
\hline & bsl p-val & 0.637 & 0.359 & 0.988 & . & $0.038^{* *}$ \\
\hline & ctrl mean & 0.30 & 6.30 & 23.34 & 7.51 & 1.58 \\
\hline & ctrl sd & 0.43 & 17.91 & 31.10 & 16.82 & 6.80 \\
\hline & obs & 3708 & 3704 & 3728 & 3704 & 3708 \\
\hline \multicolumn{2}{|c|}{ PANEL B: GUP vs. Asset Only } & & & & & \\
\hline \multirow[t]{7}{*}{ asset } & itt & -0.124 & 0.334 & 2.211 & -1.866 & -0.079 \\
\hline & se & $(0.047)$ & $(1.868)$ & $(2.037)$ & (1.164) & $(0.934)$ \\
\hline & p-val & $0.009^{* * *}$ & 0.858 & 0.278 & 0.109 & 0.932 \\
\hline & q-val & $0.060^{*}$ & 0.954 & 0.428 & 0.243 & 0.965 \\
\hline & itt, ctrls & -0.127 & 0.308 & 2.208 & -2.135 & -0.104 \\
\hline & p-val, ctrls & $0.006^{* * *}$ & 0.869 & 0.287 & $0.071^{*}$ & 0.911 \\
\hline & q-val, ctrls & $0.033^{* *}$ & 0.911 & 0.478 & 0.179 & 0.911 \\
\hline \multirow[t]{8}{*}{ GUP no sav. - asset } & diff & 0.210 & 3.311 & 1.078 & 2.914 & 0.652 \\
\hline & se & $(0.058)$ & $(2.371)$ & (3.018) & $(1.662)$ & $(1.060)$ \\
\hline & p-val & $0.000^{* * *}$ & 0.163 & 0.721 & $0.080^{*}$ & 0.539 \\
\hline & itt, ctrls & 0.205 & 3.071 & 0.114 & 2.827 & 0.607 \\
\hline & p-val, ctrls & $0.000^{* * *}$ & 0.195 & 0.970 & $0.090^{*}$ & 0.565 \\
\hline & ctrl mean & 0.30 & 6.30 & 23.34 & 7.51 & 1.58 \\
\hline & ctrl sd & 0.43 & 17.91 & 31.10 & 16.82 & 6.80 \\
\hline & obs & 4007 & 4003 & 4026 & 4002 & 4007 \\
\hline
\end{tabular}

Estimates from OLS regressions of household-level economic indices from year two (averaging over two-year outcome and midline outcomes that were collected at least one year after treatment start) on treatments. The omitted group is control households in control villages. The regression in Panel A excludes the asset only villages and includes controls for re-randomization variables and the baseline value of the outcome. The regression in Panel B includes the asset only villages (without baseline controls). Both panels include controls for employment program treatments.. We also include interviewer fixed effects and fixed effects for whether or not the household was surveyed in each midline. Standard errors clustered at unit of randomization (village for pure control, individual otherwise). We use the Benjamini-Hochberg step-up method to compute q-values, considering the 20 independent hypotheses in the table. For regressions that include asset households, we also report p-values and q-values for a specification with three two-year variables as controls, since we have no baseline controls. (See appendix for evidence that these variables were mostly not affected by the GUP or SOUP treatments.) Finally, we report p-values for the same specification using the baseline value of each outcome. We use a superscript $(+)$ to indicate a positive t-statistic. See appendix for detailed descriptions of each variable. 
Appendix Table 13: Pooled Two-Year and Three-Year Effects of GUP and Asset Only on Household-Level Livestock Flows

\begin{tabular}{|c|c|c|c|c|c|c|c|}
\hline & & $\begin{array}{c}\text { (1) } \\
\text { number of } \\
\text { goats born }\end{array}$ & $\begin{array}{c}(2) \\
\text { number of } \\
\text { goats died }\end{array}$ & $\begin{array}{c}(3) \\
\text { number of } \\
\text { goats sold }\end{array}$ & $\begin{array}{c}\text { (4) } \\
\text { number of } \\
\text { goats bought }\end{array}$ & $\begin{array}{c}(5) \\
\text { number of } \\
\text { goats eaten }\end{array}$ & $\begin{array}{c}(6) \\
\text { number of } \\
\text { goats } \\
\text { slaughtered }\end{array}$ \\
\hline \multirow[t]{7}{*}{ GUP no sav. } & itt & 0.839 & 0.662 & 0.212 & 0.017 & -0.008 & -0.006 \\
\hline & se & $(0.154)$ & $(0.154)$ & $(0.080)$ & $(0.034)$ & $(0.035)$ & $(0.034)$ \\
\hline & p-val & $0.000 * * *$ & $0.000 * * *$ & $0.008^{* * *}$ & 0.615 & 0.816 & 0.862 \\
\hline & q-val & $0.001^{* * *}$ & $0.001^{* * *}$ & $0.025^{* *}$ & 0.739 & 0.863 & 0.863 \\
\hline & itt, ctrls & 0.797 & 0.634 & 0.204 & 0.015 & -0.012 & -0.010 \\
\hline & p-val, ctrls & $0.000^{* * *}$ & $0.000^{* * *}$ & $0.011^{* *}$ & 0.653 & 0.731 & 0.776 \\
\hline & q-val, ctrls & $0.001^{* * *}$ & $0.001^{* * *}$ & $0.034^{* *}$ & 0.777 & 0.777 & 0.777 \\
\hline \multirow[t]{7}{*}{ asset } & itt & 0.373 & 0.509 & -0.054 & -0.033 & -0.028 & -0.028 \\
\hline & se & $(0.146)$ & $(0.175)$ & $(0.057)$ & $(0.039)$ & $(0.034)$ & $(0.034)$ \\
\hline & p-val & $0.011^{* *}$ & $0.004^{* * *}$ & 0.346 & 0.393 & 0.402 & 0.408 \\
\hline & q-val & $0.026^{* *}$ & $0.015^{* *}$ & 0.545 & 0.545 & 0.545 & 0.545 \\
\hline & itt, ctrls & 0.354 & 0.500 & -0.063 & -0.030 & -0.030 & -0.030 \\
\hline & p-val, ctrls & $0.016^{* *}$ & $0.004^{* * *}$ & 0.276 & 0.434 & 0.372 & 0.376 \\
\hline & q-val, ctrls & $0.038^{* *}$ & $0.017^{* *}$ & 0.552 & 0.579 & 0.565 & 0.565 \\
\hline \multirow[t]{8}{*}{ GUP no sav. - asset } & diff & 0.466 & 0.153 & 0.266 & 0.050 & 0.020 & 0.022 \\
\hline & se & $(0.212)$ & $(0.233)$ & $(0.099)$ & $(0.051)$ & $(0.048)$ & $(0.048)$ \\
\hline & p-val & $0.028^{* *}$ & 0.511 & $0.007^{* * *}$ & 0.329 & 0.676 & 0.644 \\
\hline & itt, ctrls & 0.443 & 0.134 & 0.267 & 0.045 & 0.018 & 0.021 \\
\hline & p-val, ctrls & $0.036^{* *}$ & 0.563 & $0.007^{* * *}$ & 0.377 & 0.701 & 0.665 \\
\hline & ctrl mean & 1.7 & 1.8 & 0.3 & 0.2 & 0.1 & 0.1 \\
\hline & ctrl sd & 2.0 & 2.3 & 1.0 & 0.7 & 0.4 & 0.4 \\
\hline & obs & 5539 & 5774 & 5777 & 5773 & 5775 & 5773 \\
\hline
\end{tabular}

Estimates from OLS regressions of asset-related outcomes on GUP and asset treatments. The omitted group is control households in all villages. We pool outcomes from the two-year (averaging over the two-year outcome and midline outcomes that were collected at least one year after treatment start) and three-year surveys. We control for employment program treatments. We include fixed effects for all villages except those assigned to pure control, dummies for the survey round (two-year or three-year) and dummies for whether or not the household was surveyed in each midline. Standard errors clustered at unit of randomization (village-level for pure control, individual-level otherwise). We use the Benjamini-Hochberg step-up method to compute q-values, considering the 12 independent hypotheses in the table. We also report p-values and q-values for a specification with three two-year variables as controls (average age, metal roof, household size), since we have no baseline controls. See appendix for detailed descriptions of each variable. 
Appendix Table 14: Pooled Two-Year and Three-Year Effects of GUP and Asset Only on Household-Level Asset Indices by Category

\begin{tabular}{|c|c|c|c|c|}
\hline & & $\begin{array}{c}(1) \\
\text { productive asset index }\end{array}$ & $\begin{array}{c}(2) \\
\text { agric stock value index }\end{array}$ & $\begin{array}{c}(3) \\
\text { household asset index }\end{array}$ \\
\hline \multirow[t]{7}{*}{ GUP no sav. } & itt & 0.136 & 0.084 & 0.058 \\
\hline & se & $(0.103)$ & $(0.045)$ & $(0.067)$ \\
\hline & p-val & 0.188 & $0.061^{*}$ & 0.384 \\
\hline & q-val & 0.565 & 0.365 & 0.588 \\
\hline & itt, ctrls & 0.086 & 0.063 & 0.018 \\
\hline & p-val, ctrls & 0.378 & 0.150 & 0.778 \\
\hline & q-val, ctrls & 0.839 & 0.839 & 0.934 \\
\hline \multirow[t]{7}{*}{ asset } & itt & -0.111 & 0.008 & -0.037 \\
\hline & se & $(0.129)$ & $(0.044)$ & $(0.058)$ \\
\hline & p-val & 0.392 & 0.856 & 0.523 \\
\hline & q-val & 0.588 & 0.856 & 0.628 \\
\hline & itt, ctrls & -0.105 & 0.002 & -0.025 \\
\hline & p-val, ctrls & 0.419 & 0.955 & 0.656 \\
\hline & q-val, ctrls & 0.839 & 0.956 & 0.934 \\
\hline \multirow[t]{8}{*}{ GUP no sav. - asset } & diff & 0.247 & 0.076 & 0.095 \\
\hline & se & $(0.165)$ & $(0.063)$ & $(0.089)$ \\
\hline & p-val & 0.136 & 0.231 & 0.282 \\
\hline & itt, ctrls & 0.191 & 0.060 & 0.043 \\
\hline & p-val, ctrls & 0.240 & 0.331 & 0.613 \\
\hline & ctrl mean & 0.4 & -0.0 & -0.0 \\
\hline & ctrl sd & 1.7 & 0.9 & 1.0 \\
\hline & obs & 7823 & 8123 & 7901 \\
\hline
\end{tabular}

Estimates from OLS regressions of asset-related outcomes on GUP and asset treatments. The omitted group is control households in all villages. We pool outcomes from the two-year (averaging over the two-year outcome and midline outcomes that were collected at least one year after treatment start) and three-year surveys. We control for employment program treatments. We include fixed effects for all villages except those assigned to pure control, dummies for the survey round (two-year or three-year) and dummies for whether or not the household was surveyed in each midline. Standard errors clustered at unit of randomization (village-level for pure control, individual-level otherwise). We use the Benjamini-Hochberg step-up method to compute q-values, considering the 6 independent hypotheses in the table. We also report p-values and $q$-values for a specification with three two-year variables as controls (average age, metal roof, household size), since we have no baseline controls. See appendix for detailed descriptions of each variable. 
Appendix Table 15: One-Year Effects on Consumption and Assets for Cost Benefit Analysis

\begin{tabular}{|c|c|c|c|c|c|}
\hline & & $\begin{array}{l}(1) \\
\text { yearly nondurable per } \\
\text { capita cons (usd) }\end{array}$ & $\begin{array}{c}(2) \\
\text { yearly nondurable per } \\
\text { HH cons (usd) }\end{array}$ & $\begin{array}{l}(3) \\
\text { value of assets per } \\
\text { capita (usd) }\end{array}$ & $\begin{array}{c}(4) \\
\text { value of productive } \\
\text { assets per capita (usd) }\end{array}$ \\
\hline \multirow[t]{5}{*}{ SOUP } & itt & 9.929 & 12.799 & 8.561 & 3.662 \\
\hline & se & $(30.900)$ & (183.288) & (11.921) & (10.193) \\
\hline & p-val & 0.748 & 0.944 & 0.473 & 0.720 \\
\hline & q-val & 0.921 & 0.945 & 0.921 & 0.921 \\
\hline & bsl p-val & 0.982 & 0.593 & $0.063^{*}$ & 0.142 \\
\hline \multirow[t]{5}{*}{ GUP no sav. } & itt & 38.922 & 97.950 & 34.183 & 6.967 \\
\hline & se & $(38.749)$ & (232.123) & $(13.293)$ & $(10.419)$ \\
\hline & p-val & 0.315 & 0.673 & $0.010^{* *}$ & 0.504 \\
\hline & q-val & 0.921 & 0.921 & $0.083^{*}$ & 0.921 \\
\hline & bsl p-val & $0.021^{* *}$ & $0.057^{*}$ & 0.735 & 0.969 \\
\hline \multirow[t]{5}{*}{ GUP sav. } & itt & -4.524 & -165.840 & 26.304 & 5.283 \\
\hline & se & $(37.154)$ & (219.250) & $(12.390)$ & (10.369) \\
\hline & p-val & 0.903 & 0.450 & $0.034^{* *}$ & 0.611 \\
\hline & q-val & 0.945 & 0.921 & 0.182 & 0.921 \\
\hline & bsl p-val & $0.087^{*}$ & $0.028^{* *}$ & 0.627 & 0.505 \\
\hline \multirow[t]{4}{*}{ GUP sav. - SOUP } & diff & -14.453 & -178.639 & 17.743 & 1.622 \\
\hline & se & $(44.800)$ & $(269.228)$ & $(15.332)$ & $(12.726)$ \\
\hline & p-val & 0.747 & 0.507 & 0.248 & 0.899 \\
\hline & bsl p-val & 0.165 & $0.027^{* *}$ & $0.085^{*(+)}$ & 0.118 \\
\hline \multirow[t]{6}{*}{ any GUP } & itt & 16.933 & -35.399 & 30.207 & 6.115 \\
\hline & se & $(33.934)$ & (199.658) & $(10.995)$ & $(8.957)$ \\
\hline & p-val & 0.618 & 0.859 & $0.006^{* * *}$ & 0.495 \\
\hline & q-val & 0.921 & 0.945 & $0.083^{*}$ & 0.921 \\
\hline & bsl p-val & $0.022^{* *}$ & $0.019^{* *}$ & 0.862 & 0.607 \\
\hline & obs & 1085 & 1085 & 1086 & 1081 \\
\hline
\end{tabular}

Estimates from OLS regressions of household-level outcomes at year one on treatments, used in the cost benefit analysis. The omitted group is control households in all villages. The regression in Panel A excludes the asset only villages and includes controls for re-randomization variables and the baseline value of the outcome. The regression in Panel B includes the asset only villages (without baseline controls). Both panels include controls for employment program treatments. We include fixed effects for all villages except those assigned to pure control, and dummies for whether or not the household was surveyed in each midline. Standard errors clustered at unit of randomization (village for pure control, individual otherwise). We use the Benjamini-Hochberg step-up method to compute q-values, considering the 16 independent hypotheses in the table. For regressions that include asset households, we also report p-values and q-values for a specification with three two-year variables as controls, since we have no baseline controls. (See appendix for evidence that these variables were mostly not affected by the GUP or SOUP treatments.) Finally, we report p-values for the same specification using the baseline value of each outcome. We use a superscript $(+)$ to indicate a positive t-statistic. See appendix for detailed descriptions of each variable. 
Appendix Table 16: Two-Year Effects on Consumption and Assets for Cost Benefit Analysis

\begin{tabular}{|c|c|c|c|c|c|}
\hline & & $\begin{array}{c}(1) \\
\text { yearly nondurable } \\
\text { per capita cons } \\
\text { (usd) }\end{array}$ & $\begin{array}{l}(2) \\
\text { yearly nondurable } \\
\text { per HH cons (usd) }\end{array}$ & $\begin{array}{c}(3) \\
\text { value of assets per } \\
\text { capita (usd) }\end{array}$ & $\begin{array}{l}(4) \\
\text { value of productive } \\
\text { assets per capita } \\
\text { (usd) }\end{array}$ \\
\hline \multicolumn{6}{|c|}{ PANEL A: GUP vs. SOUP } \\
\hline \multirow[t]{5}{*}{ SOUP } & itt & 65.099 & 419.828 & 6.909 & 1.948 \\
\hline & se & $(22.257)$ & $(148.924)$ & $(6.291)$ & $(5.629)$ \\
\hline & p-val & $0.003^{* * *}$ & $0.005^{* * *}$ & 0.272 & 0.729 \\
\hline & q-val & $0.020^{* *}$ & $0.020^{* *}$ & 0.419 & 0.854 \\
\hline & bsl p-val & 0.982 & 0.593 & $0.063^{*}$ & 0.142 \\
\hline \multirow[t]{5}{*}{ GUP no sav. } & & 65.073 & 659.870 & 14.620 & 0.399 \\
\hline & & $(24.839)$ & $(188.496)$ & $(5.566)$ & $(4.426)$ \\
\hline & p-val & $0.009^{* * *}$ & $0.000^{* * *}$ & $0.009^{* * *}$ & 0.928 \\
\hline & q-val & $0.026^{* *}$ & $0.010^{* * *}$ & $0.026^{* *}$ & 0.929 \\
\hline & bsl p-val & $0.021^{* *}$ & $0.057^{*}$ & 0.735 & 0.969 \\
\hline \multirow{5}{*}{ GUP sav. } & & 41.534 & 321.312 & 3.285 & -11.298 \\
\hline & & $(23.652)$ & $(173.745)$ & $(4.915)$ & $(3.952)$ \\
\hline & p-val & $0.079^{*}$ & $0.065^{*}$ & 0.504 & $0.004^{* * *}$ \\
\hline & q-val & 0.145 & 0.130 & 0.697 & $0.020^{* *}$ \\
\hline & bsl p-val & $0.087^{*}$ & $0.028^{* *}$ & 0.627 & 0.505 \\
\hline \multirow[t]{4}{*}{ GUP sav. - SOUP } & diff & -23.565 & -98.515 & -3.624 & -13.245 \\
\hline & & $(29.322)$ & $(207.086)$ & $(7.260)$ & $(6.159)$ \\
\hline & p-val & 0.422 & 0.634 & 0.618 & $0.032^{* *}$ \\
\hline & bsl p-val & 0.165 & $0.027^{* *}$ & $0.085^{*(+)}$ & 0.118 \\
\hline \multirow[t]{6}{*}{ any GUP } & & 53.180 & 488.938 & 8.843 & -5.493 \\
\hline & & $(21.090)$ & $(157.440)$ & $(4.560)$ & $(3.675)$ \\
\hline & p-val & $0.012^{* *}$ & $0.002^{* * *}$ & $0.053^{*}$ & 0.135 \\
\hline & q-val & $0.030^{* *}$ & $0.020^{* *}$ & 0.117 & 0.226 \\
\hline & bsl p-val & $0.022^{* *}$ & $0.019^{* *}$ & 0.862 & 0.607 \\
\hline & obs & 3671 & 3671 & 3777 & 3629 \\
\hline \multicolumn{6}{|c|}{ PANEL B: GUP vs. Asset Only } \\
\hline \multirow[t]{7}{*}{ asset } & itt & -8.279 & -48.295 & -5.613 & -2.582 \\
\hline & se & $(33.693)$ & $(201.360)$ & $(8.775)$ & $(6.831)$ \\
\hline & p-val & 0.806 & 0.810 & 0.522 & 0.706 \\
\hline & q-val & 0.854 & 0.854 & 0.697 & 0.854 \\
\hline & itt, ctrls & -2.524 & -22.572 & -5.976 & -2.563 \\
\hline & p-val, ctrls & 0.936 & 0.905 & 0.503 & 0.707 \\
\hline & q-val, ctrls & 0.937 & 0.937 & 0.937 & 0.937 \\
\hline \multirow[t]{6}{*}{ GUP no sav. - asset } & diff & 56.243 & 710.976 & 19.502 & 2.561 \\
\hline & se & $(42.734)$ & $(280.621)$ & $(10.653)$ & $(8.219)$ \\
\hline & p-val & 0.188 & $0.011^{* *}$ & $0.067^{*}$ & 0.755 \\
\hline & itt, ctrls & 66.160 & 513.495 & 21.194 & 2.647 \\
\hline & p-val, ctrls & $0.099^{*}$ & $0.053^{*}$ & $0.048^{* *}$ & 0.747 \\
\hline & obs & 3970 & 3970 & 4097 & 3922 \\
\hline
\end{tabular}

Estimates from OLS regressions of household-level outcomes at year two on treatments, used in the cost benefit analysis. The omitted group is control households in all villages. The regression in Panel A excludes the asset only villages and includes controls for re-randomization variables and the baseline value of the outcome. The regression in Panel B includes the asset only villages (without baseline controls). Both panels include controls for employment program treatments. We include fixed effects for all villages except those assigned to pure control, and dummies for whether or not the household was surveyed in each midline. Standard errors clustered at unit of randomization (village for pure control, individual otherwise). We use the Benjamini-Hochberg step-up method to compute q-values, considering the 20 independent hypotheses in the table. For regressions that include asset households, we also report p-values and q-values for a specification with three two-year variables as controls, since we have no baseline controls. (See appendix for evidence that these variables were mostly not affected by the GUP or SOUP treatments.) Finally, we report p-values for the same specification using the baseline value of each outcome. We use a superscript $(+)$ to indicate a positive t-statistic. See appendix for detailed descriptions of each variable. 
Appendix Table 17: Three-Year Effects on Consumption and Assets for Cost Benefit Analysis

\begin{tabular}{|c|c|c|c|c|c|}
\hline & & $\begin{array}{c}(1) \\
\text { yearly nondurable } \\
\text { per capita cons } \\
\text { (usd) }\end{array}$ & $\begin{array}{c}(2) \\
\text { yearly nondurable } \\
\text { per HH cons (usd) }\end{array}$ & $\begin{array}{l}(3) \\
\text { value of assets per } \\
\text { capita (usd) }\end{array}$ & $\begin{array}{c}(4) \\
\text { value of productive } \\
\text { assets per capita } \\
\text { (usd) }\end{array}$ \\
\hline \multicolumn{6}{|c|}{ PANEL A: GUP vs. SOUP } \\
\hline \multirow[t]{5}{*}{ SOUP } & itt & -4.746 & 46.211 & -0.535 & -2.918 \\
\hline & se & (15.215) & (121.466) & $(5.235)$ & $(4.707)$ \\
\hline & p-val & 0.755 & 0.704 & 0.919 & 0.535 \\
\hline & q-val & 0.889 & 0.880 & 0.967 & 0.868 \\
\hline & bsl p-val & 0.982 & 0.593 & $0.063^{*}$ & 0.142 \\
\hline \multirow[t]{5}{*}{ GUP no sav. } & & 57.036 & 469.008 & 18.173 & 2.154 \\
\hline & & $(20.737)$ & $(180.315)$ & $(5.811)$ & $(4.840)$ \\
\hline & p-val & $0.006^{* * *}$ & $0.009^{* * *}$ & $0.002^{* * *}$ & 0.656 \\
\hline & q-val & $0.030^{* *}$ & $0.038^{* *}$ & $0.018^{* *}$ & 0.876 \\
\hline & bsl p-val & $0.021^{* *}$ & $0.057^{*}$ & 0.735 & 0.969 \\
\hline \multirow[t]{5}{*}{ GUP sav. } & & 22.679 & 174.593 & 14.937 & 2.700 \\
\hline & & $(16.396)$ & $(140.947)$ & $(5.397)$ & $(4.331)$ \\
\hline & p-val & 0.167 & 0.216 & $0.006^{* * *}$ & 0.533 \\
\hline & q-val & 0.417 & 0.480 & $0.030^{* *}$ & 0.868 \\
\hline & bsl p-val & $0.087^{*}$ & $0.028^{* *}$ & 0.627 & 0.505 \\
\hline \multirow[t]{4}{*}{ GUP sav. - SOUP } & diff & 27.425 & 128.382 & 15.472 & 5.618 \\
\hline & & $(20.879)$ & $(172.918)$ & $(7.090)$ & $(5.959)$ \\
\hline & p-val & 0.189 & 0.458 & $0.029^{* *}$ & 0.346 \\
\hline & bsl p-val & 0.165 & $0.027^{* *}$ & $0.085^{*(+)}$ & 0.118 \\
\hline \multirow[t]{6}{*}{ any GUP } & & 40.036 & 323.487 & 16.549 & 2.424 \\
\hline & & $(16.248)$ & $(139.696)$ & $(4.872)$ & $(4.024)$ \\
\hline & p-val & $0.014^{* *}$ & $0.021^{* *}$ & $0.001^{* * *}$ & 0.547 \\
\hline & q-val & $0.047^{* *}$ & $0.060^{*}$ & $0.014^{* *}$ & 0.868 \\
\hline & bsl p-val & $0.022^{* *}$ & $0.019^{* *}$ & 0.862 & 0.607 \\
\hline & obs & 3597 & 3597 & 3755 & 3569 \\
\hline \multicolumn{2}{|c|}{ PANEL B: GUP vs. Asset Only } & & & & \\
\hline \multirow[t]{7}{*}{ asset } & itt & -0.837 & 107.353 & -1.005 & -2.795 \\
\hline & se & $(24.390)$ & $(185.866)$ & $(8.600)$ & $(6.065)$ \\
\hline & p-val & 0.973 & 0.564 & 0.907 & 0.645 \\
\hline & q-val & 0.973 & 0.868 & 0.967 & 0.876 \\
\hline & itt, ctrls & 0.586 & 90.595 & -1.306 & -3.035 \\
\hline & p-val, ctrls & 0.981 & 0.612 & 0.879 & 0.618 \\
\hline & q-val, ctrls & 0.982 & 0.982 & 0.982 & 0.982 \\
\hline \multirow[t]{6}{*}{ GUP no sav. - asset } & diff & 49.017 & 380.696 & 18.459 & 4.964 \\
\hline & se & $(32.418)$ & $(265.223)$ & (10.591) & $(7.806)$ \\
\hline & p-val & 0.131 & 0.151 & $0.081^{*}$ & 0.525 \\
\hline & itt, ctrls & 53.151 & 283.539 & 19.466 & 5.313 \\
\hline & p-val, ctrls & 0.102 & 0.264 & $0.066^{*}$ & 0.497 \\
\hline & obs & 3883 & 3883 & 4076 & 3857 \\
\hline
\end{tabular}

Estimates from OLS regressions of household-level outcomes at year three on treatments, used in the cost benefit analysis. The omitted group is control households in all villages. The regression in Panel A excludes the asset only villages and includes controls for re-randomization variables and the baseline value of the outcome. The regression in Panel B includes the asset only villages (without baseline controls). Both panels include controls for employment program treatments. We include fixed effects for all villages except those assigned to pure control, and dummies for whether or not the household was surveyed in each midline. Standard errors clustered at unit of randomization (village for pure control, individual otherwise). We use the Benjamini-Hochberg step-up method to compute q-values, considering the 20 independent hypotheses in the table. For regressions that include asset households, we also report p-values and q-values for a specification with three two-year variables as controls, since we have no baseline controls. (See appendix for evidence that these variables were mostly not affected by the GUP or SOUP treatments.) Finally, we report p-values for the same specification using the baseline value of each outcome. We use a superscript $(+)$ to indicate a positive t-statistic. See appendix for detailed descriptions of each variable. 


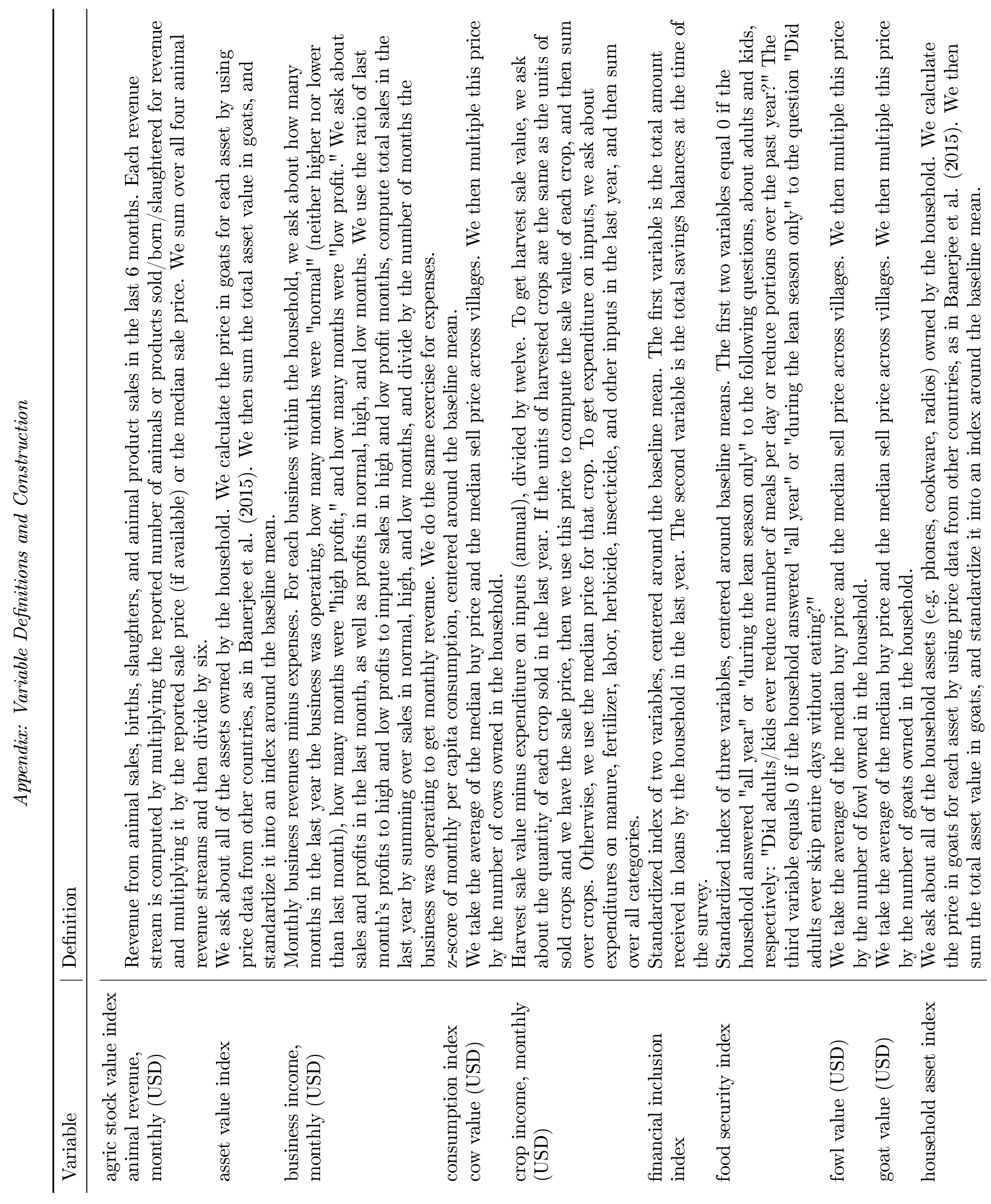




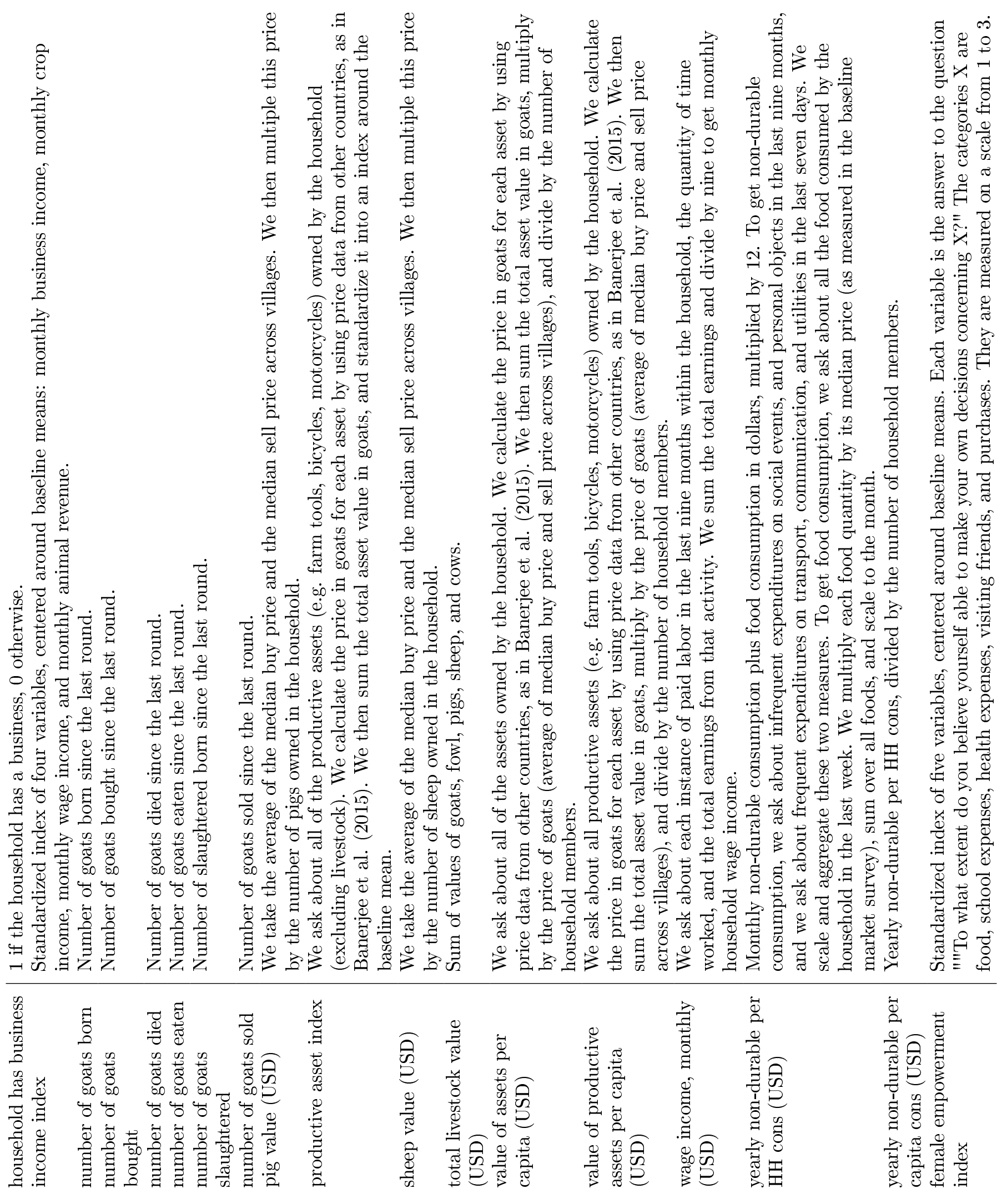



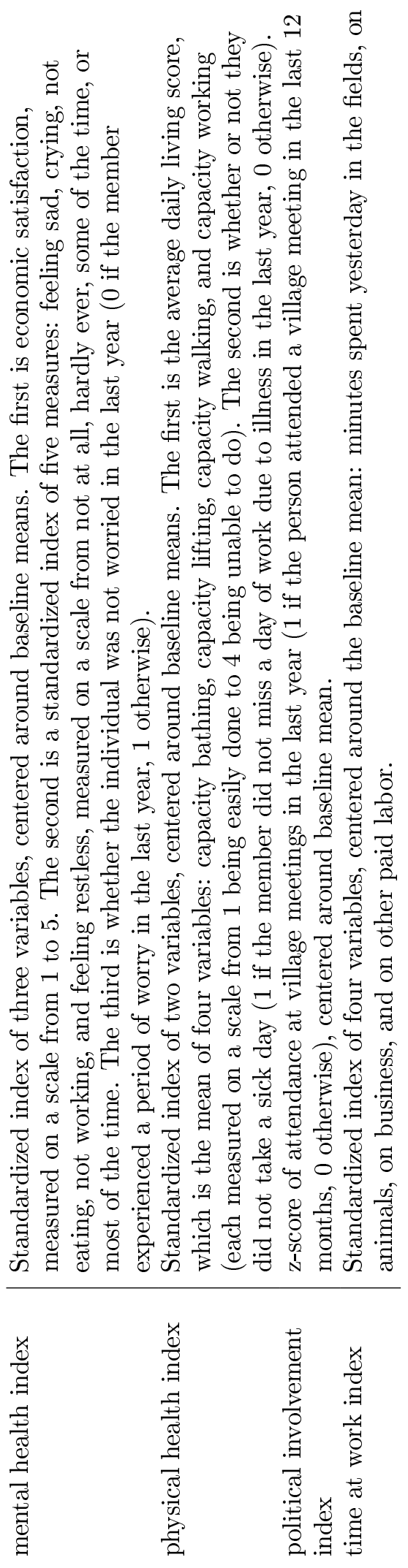